\title{
1. INTRODUCTION, OBJECTIVES, AND PRINCIPAL RESULTS: OCEAN DRILLING PROGRAM LEG 103, WEST GALICIA MARGIN ${ }^{1}$
}

\author{
Shipboard Scientific Party ${ }^{2}$
}

\section{INTRODUCTION}

Galicia margin, northwest of the Iberian Peninsula (Fig. 1), is a starved passive ocean margin with only a thin $(0-4 \mathrm{~km})$ sedimentary cover above acoustic basement. Seismic and bathymetric studies and dredge hauls reveal many of the features considered typical of passive ocean margins (Montadert et al., 1974, 1979; Groupe Galice, 1979; Boillot et al., 1979, 1980). Rift structures, apparent on seismic profiles, control the present-day morphology (Laughton et al., 1975; Vanney et al., 1979; Lallemand et al., 1985; Sibuet et al., this volume). The continental basement is broken by normal, possibly listric, faults into narrow $(10-20 \mathrm{~km})$, elongate $(60-100 \mathrm{~km})$ tilted blocks trending north and dipping gently east, forming a series of half grabens. On the western, uplifted side of some blocks, basement and possibly pre-rift sedimentary rocks crop out (Dupeuble et al.,

${ }^{1}$ Boillot, G., Winterer, E. L., Meyer, A. W., et al., Proc., Init. Repts. (Pt. A), $O D P, 103$.

2 Gilbert Boillot (Co-Chief Scientist), Laboratoire de Géodynamique SousMarine, Université Pierre et Marie Curie, B.P. 48, 06230, Villefranche-sur-Mer, France; Edward L. Winterer (Co-Chief Scientist), Graduate Research Division A012-W, Scripps Institution of Oceanography, La Jolla, CA 92093; Audrey W. Meyer (ODP Staff Scientist), Ocean Drilling Program, Texas A\&M University, College Station, TX 77843-3469; Joseph Applegate, Department of Geology, Florida State University, Tallahassee, FL 32306; Miriam Baltuck, Department of Geology, Tulane University, New Orleans, LA 70118 (current address: NASA Headquarters, Code EEL, Washington, D.C. 20546); James A. Bergen, Department of Geology, Florida State University, Tallahassee, FL 32306; M. C. Comas, Departamento Estratigrafia y Paleontologia, Facultad de Ciencias, Universidad de Granada, 18001 Granada, Spain; Thomas A. Davies, Institute for Geophysics, University of Texas at Austin, 4920 North IH 35, Austin, TX 78751; Keith Dunham, Department of Atmospheric and Oceanic Sciences, University of Michigan, 2455 Hayward Avenue, Ann Arbor, MI 48109 (current address: P.O. Box 13, Pequat Lakes, MN 56478); Cynthia A. Evans, Department of Geology, Colgate University, Hamilton, NY 13346 (current address: Lamont-Doherty Geological Observatory, Palisades, NY 10964); Jacques Girardeau, Laboratoire de Materiaux Terrestres, I.P.G., 4 Place Jussieu, 75252 Paris Cedex 05, France; David Goldberg, Lamont-Doherty Geological Observatory, Palisades, NY 10964; Janet Haggerty, Department of Geology, University of Tulsa, 600 S. College Avenue, Tulsa, OK 74104; Lubomir F. Jansa, Atlantic Geoscience Center, Bedford Institute of Oceanography, Dartmouth, Nova Scotia B2Y 4A2, Canada; Jeffrey A. Johnson, Department of Earth and Space Sciences, University of California, Los Angeles, CA 90024 (current address: 9449 Briar Forest Drive, No. 3544, Houston, TX 77063); Junzo Kasahara, Earthquake Research Institute, University of Tokyo, 1,1,1 Yayoi, Bunkyo, Tokyo 113, Japan (current address: Nippon Schlumberger K.K., 2-1 Fuchinobe, 2-chome, Sagamihara-shi, Kanagawa-Ken, 229, Japan); Jean-Paul Loreau, Laboratoire de Géologie, Museum National D'Histoire Naturelle, 43 Rue Buffon, 75005 Paris, France; Emilio Luna, Hispanoil, Pez Volador No. 2, 28007 Madrid, Spain; Miche Moullade, Laboratoire de Géologie et Micropaleontologie Marines, Université de Nice, Parc Valrose, 06034 Nice Cedex, France; James Ogg, Geological Research Division A-012, Scripps Institution of Oceanography, La Jolla, CA 92093 (current address: Dept. Earth and Atmospheric Sciences, Purdue University, W. Lafayette, IN 47907); Massimo Sarti, Istituto di Geologia, Universitá di Ferrara, Corso Ercole d'Este, 32, 44100 Ferrara, Italy; Jürgen Thurow, Institut und Museum für Geologie und Paleontologie, Universität Tübingen, Sigwartstr. 10, D-7400 Tübingen, Federal Republic of Germany; Mark A. Williamson, Atlantic Geoscience Centre, Geological Survey of Canada, Bedford Institute of Oceanography, Box 1006, Dartmouth, Nova Scotia B2Y 4A2, Canada (current address: Shell Canada Ltd., P.O. Box 100, Stn. M, Calgary, Alberta T2P 2H5, Canada). this volume). These conditions made this an attractive margin for drilling on Ocean Drilling Program (ODP) Leg 103 because we thought that the basement and the oldest sedimentary strata were within drilling reach of the JOIDES Resolution. We expected the results of coring and logging here to elucidate the history of rifting, subsidence, and sedimentation on this margin and the relation of these processes to the initiation and progressive opening of the adjacent North Atlantic. We also hoped to gain information on the transition between continental and oceanic crusts and on the evolution of the more thickly sedimented, and hence less accessible, conjugate margin of North America.

The first scientific drilling on the Iberian margin took place in 1976, when the GLOMAR Challenger drilled Site 398 near Vigo Seamount, off northern Portugal, during Deep Sea Drilling Project (DSDP) Leg 47B (Sibuet, Ryan, et al., 1979). Coring penetrated $1750 \mathrm{~m}$ of Cenozoic and Cretaceous sediments. The sequence comprised both sediments deposited during rifting (syn-rift) and sediments deposited subsequently during seafloor spreading (post-rift). Pre-rift sedimentary and basement rocks and the deeper parts of the syn-rift sequence, seen on seismic profiles, were not penetrated. A major result of Site 398 drilling was the dating of the boundary, or "break-up unconformity," separating late Aptian, syn-rift, and lower Albian, postrift, strata.

ODP Leg 103, which began on 25 April 1985 in Ponta Delgada, Azores, and ended in Bremerhaven, Federal Republic of Germany, on 19 June 1985, drilled five sites (Table 1). Three of these (Sites 638, 639, and 641) extended the results of DSDP Leg 47B through the syn- and possibly pre-rift strata by drilling and coring through $1200 \mathrm{~m}$ of Lower Cretaceous (Albian-Valanginian) to Upper Jurassic (Tithonian) rocks to the top of basement rock on the deep western edge of the margin. At Site 637 near the boundary between oceanic and continental crusts, coring recovered upper-mantle peridotite. Additionally, Site 640 was drilled on the summit of the ridge closest to the transition between continental and oceanic crusts, over a deep reflector widely thought to represent the ductile/brittle continental-crust boundary, into which listric faults are rooted.

Despite our pre-cruise optimism, drilling on Galicia margin proved to be a technical challenge. A series of operational difficulties, caused largely by the nature of the rocks through which we were attempting to drill, thwarted all attempts at deep penetration. Site 639, for example, consists of a series of six short holes, which sampled different stratigraphic levels in the same sequence exposed at the edge of a fault block. Nevertheless, with the aid of seismic profiles, the results of Leg 103 can be assembled into a composite stratigraphic sequence, which permits us to answer the major scientific questions about the character of the basement rock and the history of the margin.

In this chapter, we first describe the regional setting of the Galicia margin region. We then discuss specific Leg 103 drilling objectives and finally present a summary of the results from the cruise. More detailed site results are given in the site chapters (this volume). 


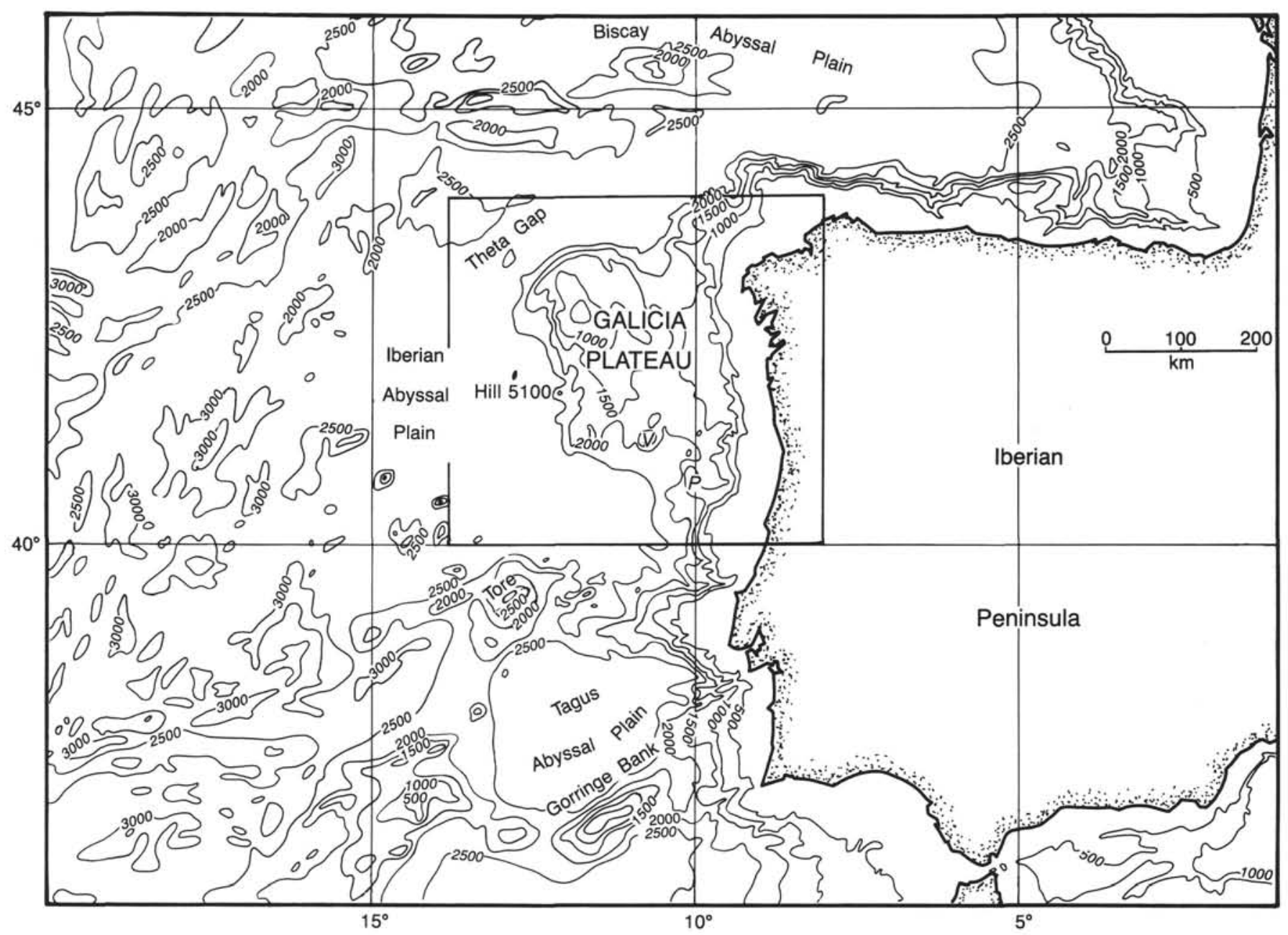

Figure 1. Atlantic margins of Iberia and adjacent abyssal plains. The area shown in Figure 2 is outlined. Contours in meters; contour interval, $500 \mathrm{~m}$. $\mathrm{V}=$ Vigo Seamount; $\mathrm{P}=$ Porto Seamount. From Laughton et al. (1975).

Table 1. Summary of Leg 103 drilling.

\begin{tabular}{|c|c|c|c|c|c|c|c|c|c|}
\hline Hole & Dates (1985) & Latitude & Longitude & $\begin{array}{l}\text { Water } \\
\text { depth }^{\mathrm{a}}\end{array}$ & Penetration & $\begin{array}{l}\text { No. of } \\
\text { cores }\end{array}$ & $\begin{array}{l}\text { Meters } \\
\text { cored }\end{array}$ & $\begin{array}{l}\text { Meters } \\
\text { recovered }\end{array}$ & $\begin{array}{c}\text { Average } \\
\text { percentage } \\
\text { recovered }\end{array}$ \\
\hline $637 \mathrm{~A}$ & 28 Apr-4 May & $42^{\circ} 05.3^{\prime} \mathrm{N}$ & $12^{\circ} 51.8^{\prime} \mathrm{W}$ & 5307 & 285.6 & 30 & 285.6 & 91.2 & 32 \\
\hline $638 \mathrm{~A}$ & 5 May-6 May & $42^{\circ} 09.2^{\prime} \mathrm{N}$ & $12^{\circ} 11.8^{\prime} \mathrm{W}$ & 4661 & 44.0 & none & 0.0 & 0.0 & 00 \\
\hline $638 \mathrm{~B}$ & 6 May-12 May & $42^{\circ} 09.2^{\prime} \mathrm{N}$ & $12^{\circ} 11.8^{\prime} \mathrm{W}$ & 4661 & 431.1 & 45 & 431.1 & 210.5 & 49 \\
\hline $638 \mathrm{C}$ & 12 May-23 May & $42^{\circ} 09.2^{\prime} \mathrm{N}$ & $12^{\circ} 11.8^{\prime} \mathrm{W}$ & 4661 & 547.2 & 14 & 135.3 & 37.7 & 28 \\
\hline $639 A$ & 23 May-25 May & $42^{\circ} 08.6^{\prime} \mathrm{N}$ & $12^{\circ} 14.9^{\prime} \mathrm{W}$ & 4720 & 89.8 & 10 & 89.9 & 35.43 & 39 \\
\hline $639 \mathrm{~B}$ & 26 May-27 May & $42^{\circ} 08.6^{\prime} \mathrm{N}$ & $12^{\circ} 15.0^{\prime} \mathrm{W}$ & 4735 & 80.0 & 4 & 80.0 & 12.6 & 16 \\
\hline $639 \mathrm{C}$ & 27 May-27 May & $42^{\circ} 08.6^{\prime} \mathrm{N}$ & $12^{\circ} 15.1^{\prime} \mathrm{W}$ & 4756 & 99.8 & 2 & 21.8 & 4.8 & 22 \\
\hline 639D & 27 May-3 Jun & $42^{\circ} 08.6^{\prime} \mathrm{N}$ & $12^{\circ} 15.3^{\prime} \mathrm{W}$ & 4748 & 293.1 & 13 & 115.5 & 24.15 & 21 \\
\hline $639 \mathrm{E}$ & 6 Jun-7 Jun & $42^{\circ} 08.6^{\prime} \mathrm{N}$ & $12^{\circ} 15.4^{\prime} \mathrm{W}$ & 4754 & 234.9 & 4 & 35.5 & 1.8 & 5 \\
\hline $639 \mathrm{~F}$ & 7 Jun-8 Jun & $42^{\circ} 08.6^{\prime} \mathrm{N}$ & $12^{\circ} 15.5^{\prime} \mathrm{W}$ & 4754 & 250.8 & 2 & 13.0 & 1.03 & 8 \\
\hline $640 \mathrm{~A}$ & 4 Jun-6 Jun & $42^{\circ} 00.7^{\prime} \mathrm{N}$ & $12^{\circ} 27.8^{\prime} \mathrm{W}$ & 5196 & 232.2 & 9 & 86.8 & 15.6 & 18 \\
\hline $641 \mathrm{~A}$ & 8 Jun-10 Jun & $42^{\circ} 09.3^{\prime} \mathrm{N}$ & $12^{\circ} 10.9^{\prime} \mathrm{W}$ & 4636 & 63.6 & 7 & 63.6 & 40.34 & 63.4 \\
\hline $641 \mathrm{~B}$ & 10 Jun-11 Jun & $42^{\circ} 09.3^{\prime} \mathrm{N}$ & $12^{\circ} 10.9^{\prime} \mathrm{W}$ & 4639 & 35.0 & none & 0.0 & 0.0 & 00 \\
\hline $641 \mathrm{C}$ & 11 Jun-15 Jun & $42^{\circ} 09.3^{\prime} \mathrm{N}$ & $12^{\circ} 10.9^{\prime} \mathrm{W}$ & 4640 & 305.2 & 16 & 154.3 & 112.52 & 72.9 \\
\hline
\end{tabular}

${ }^{\text {a }}$ Sea level; corrected $\mathrm{m}$, echo-sounding.

\section{REGIONAL BACKGROUND}

\section{Bathymetry and Morphology}

The northern Iberian continental margin (Fig. 1) is morphologically complex and anomalous (Fig. 2). The province of Galicia, Spain, is bordered to the west by a narrow $(30-\mathrm{km})$ shelf ad- jacent to a wide and deep, U-shaped offshore trough $(350 \mathrm{~km}$ long, $100 \mathrm{~km}$ wide, and 3-4 km deep). Farther seaward, several marginal plateaus form a discontinuous barrier between the basin and the Iberian Abyssal Plain. These plateaus, from north to south, include Galicia (summit at $600 \mathrm{~m}$ depth), Vigo $(2100 \mathrm{~m})$, Vasco da Gama $(1750 \mathrm{~m})$, and Porto $(2200 \mathrm{~m})$ (Ber- 


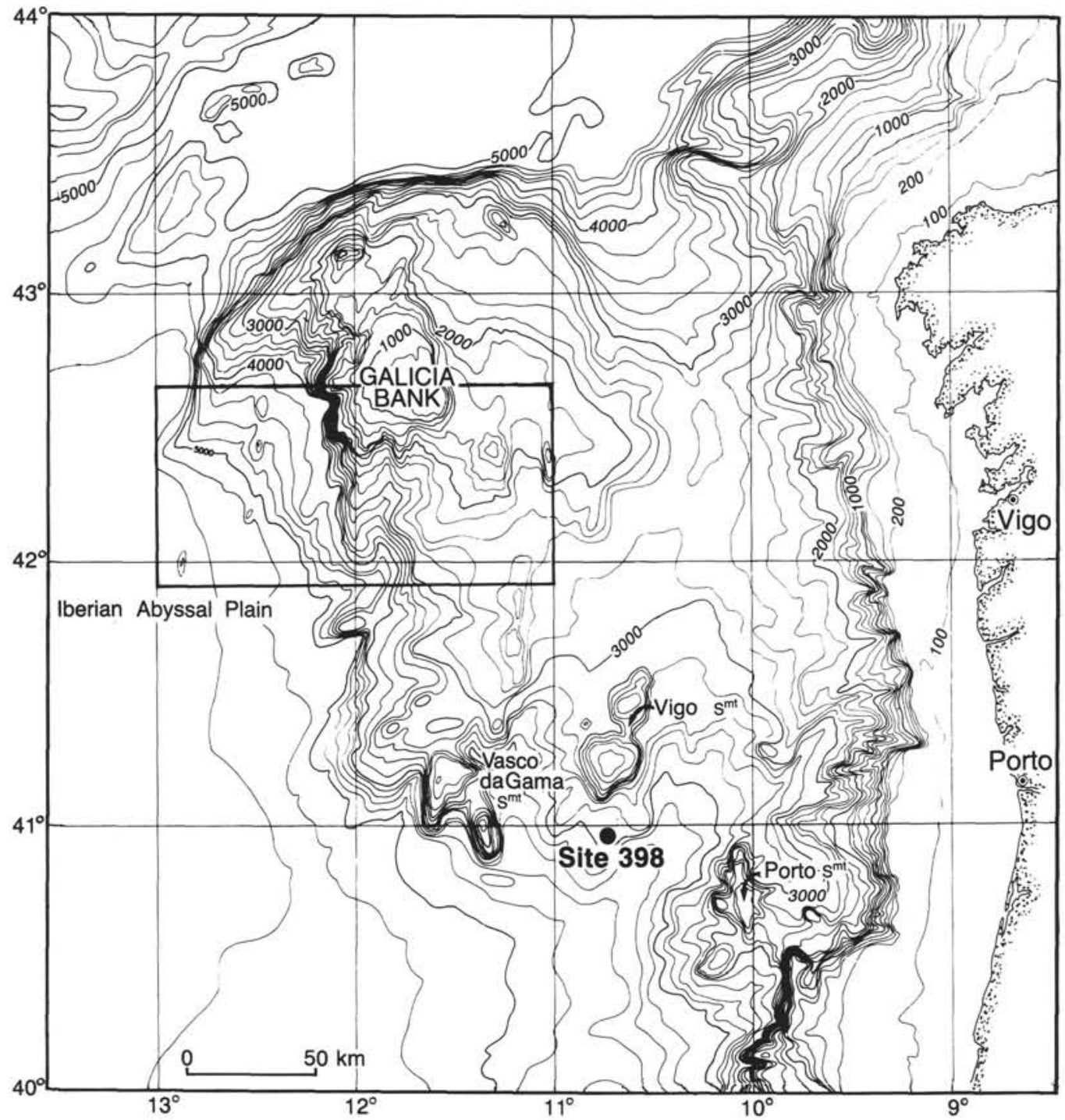

Figure 2. Bathymetry of the continental margin northwest of the Iberian Peninsula. Contours in meters; contour interval, $200 \mathrm{~m}$. The area shown in Figure 3 is outlined, and location of DSDP Site 398 is shown. From Vanney et al. (1979).

thois et al., 1965; Laughton et al., 1975; Vanney et al., 1979; Roberts and Kidd, 1984; Mougenot et al., 1984, 1986; Lallemand et al., 1985).

Several different interpretations have been applied to these plateaus. According to Montadert et al. (1974), they are horsts inherited from Mesozoic rifting of the margin. Mauffret et al. (1978) and Boillot et al. (1979), on the other hand, argued that the relief results from Eocene tectonic movements. Actually, the plateaus are Mesozoic tilted blocks and grabens that were reactivated and uplifted by early Cenozoic Pyrenean tectonics, except Vigo Seamount, which is an uplifted inverted basin (Mougenot et al., 1984).

Although the sites chosen for drilling during Leg 103 are in an area that appears to be relatively unaffected by Cenozoic deformation, the bathymetric relief is nonetheless strong (Fig. 3). The main ridges and steps trend north, but there is a secondary trend of about $\mathrm{N} 60^{\circ} \mathrm{E}$. This morphology is fault controlled and reflects the underlying structure: the north-trending ridges and their accompanying seaward-facing scarps are the upper edges of tilted fault blocks formed by Early Cretaceous rifting, whereas the scarps trending northeast are probably controlled by oblique faults. These structures are clearly delineated in the bathymetry along the western Galicia margin because it is a starved margin that is covered only thinly by post-rift sediments.

\section{Magnetic Anomalies and Plate Kinematics}

Seaward of the Galicia and the conjugate Newfoundland margins, the oldest recognizable magnetic anomaly is the J, or M0, anomaly (late Aptian, $110 \mathrm{Ma}$ ) (Fig. 4). Because this anomaly can be clearly traced northward to only about $41^{\circ} 30^{\prime} \mathrm{N}$, it may be that the oldest oceanic crust adjacent to western Galicia margin is slightly younger than $110 \mathrm{Ma}$. Certainly, this crust is within the Cretaceous magnetic quiet zone (Kristoffersen, 1978; Groupe Galice, 1979; Sibuet and Ryan, 1979; Olivet et al., 1984; Klitgord and Schouten, in press; Schouten et al., in press).

Seafloor spreading opened the Bay of Biscay from early Albian to about Santonian time (approximately 105-80 Ma), and, at the end of this epoch of spreading, the Bay was somewhat wider than it is today (Olivet, 1978). Later, during the Paleocene and Eocene, convergence between the Iberian and European plates resulted in crustal shortening and uplift along the north Spanish margin, extending as far west as Galicia Bank (Gri- 


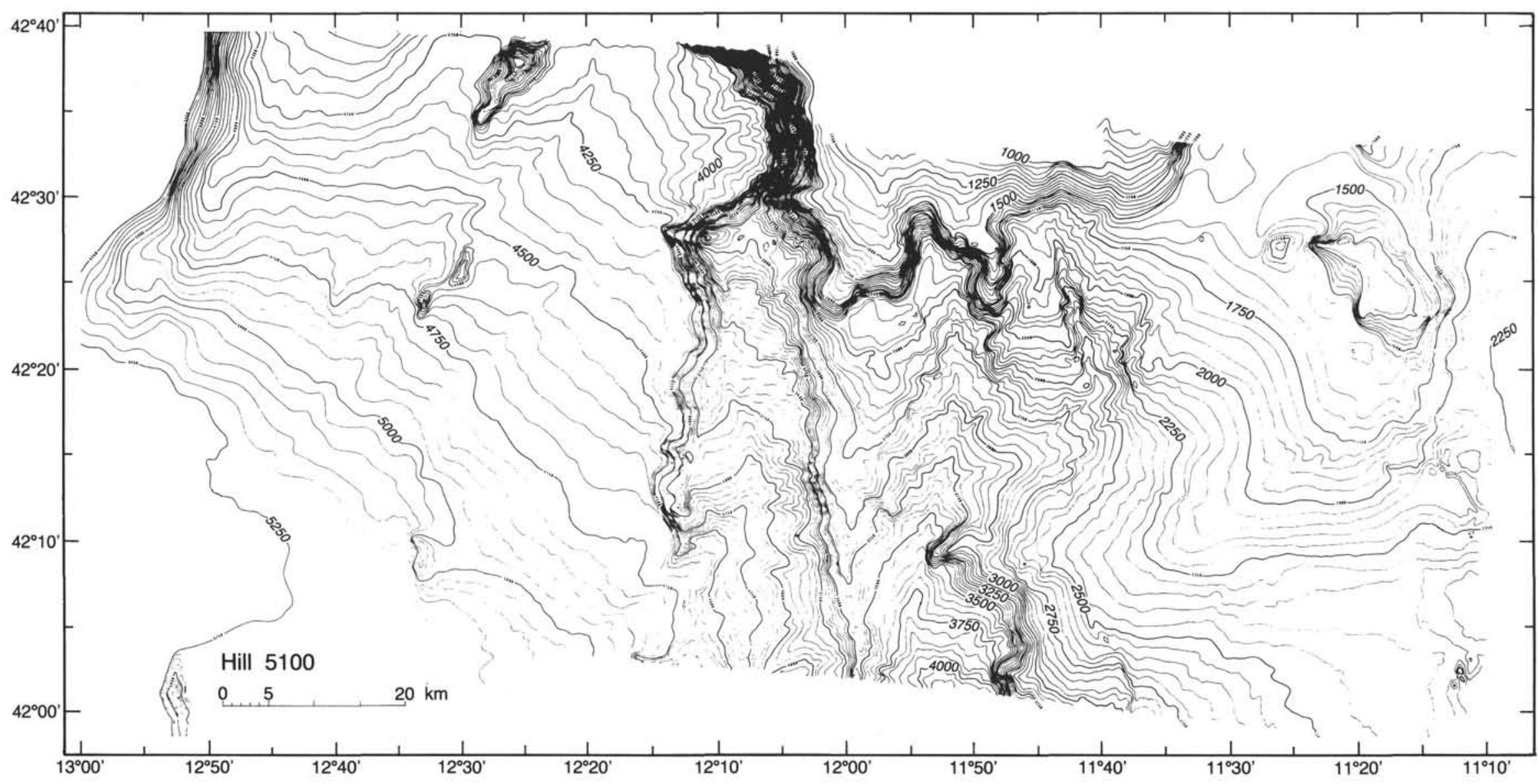

Figure 3. Detailed bathymetry of the west-central part of the Galicia margin, constructed from Sea Beam data collected during the Seagal cruise of $R / V$ Jean Charcot. After Sibuet et al. (this volume). 
maud et al., 1982) (Fig. 4). The complex morphology of parts of western Galicia margin results partly from these Pyrenean events.

\section{Structure of the Margin}

The rift structures of the margin, beneath the post-rift sedimentary cover, appear clearly on seismic records (Montadert et al., 1974, 1979; Chenet et al., 1982; Sibuet et al., this volume). According to the interpretation of Boillot (1986), the north-trending listric faults and elongate tilted blocks are offset by northeast-trending transverse faults, acting as normal to normal transform faults during rifting (Fig. 5). The distance between blocks ranges from 12 to $20 \mathrm{~km}$, increasing westward in the direction of

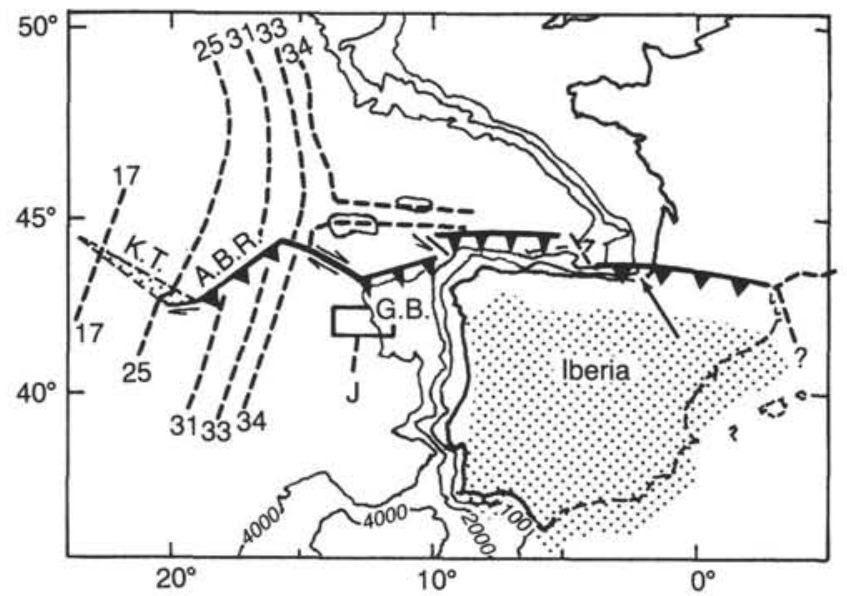

Figure 4. Eocene plate boundary and magnetic anomalies in the northeast Atlantic. The shaded area represents the reconstructed position of Iberia when anomaly 33 was formed. Arrow in northern Spain indicates direction of motion of Iberia with respect to Europe during Paleocene and Eocene time. G.B. = Galicia Bank; K.T. = King's Trough; A.B.R. $=$ Azores-Biscay Rise. Leg 103 drilling area is outlined. Bathymetric contours in meters. Modified from Grimaud et al. (1982); magnetic anomalies from Kristoffersen (1978).

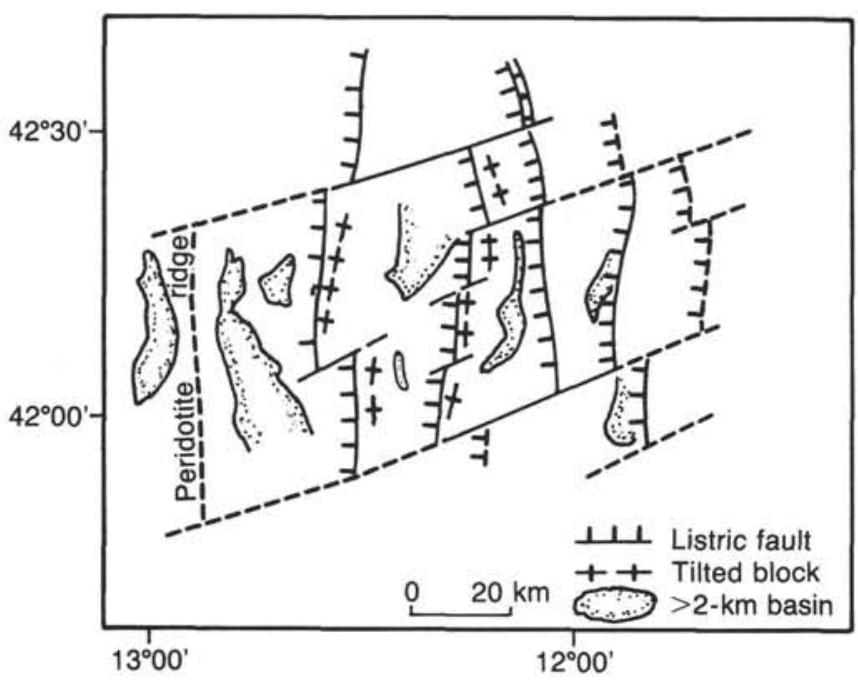

Figure 5. Simplified and interpretative structural map of the west-central part of the Galicia margin. For general location, see Figure 2. Interpretation from Boillot (1986). deeper water and of probable thinner crust (Fig. 6). Outcrops of acoustic basement tend to occur along scarps of normal northsouth faults and of possible transverse faults, and the half grabens contain the maximum thickness of the sediments (approximately $3 \mathrm{~km}$ ).

The deeper part of the margin, $50 \mathrm{~km}$ wide, slopes gently to the west, from 4800 to $5300 \mathrm{~m}$ (Fig. 2). This part of the margin is characterized by a deep, strong and almost continuous reflector beneath the "acoustic basement" (Fig. 6), labeled $S$ by Montadert et al. (1979). The S reflector, between 1.5 and $3 \mathrm{~s}$ (two-way traveltime) below the seafloor, was interpreted by de Charpal et al. (1978), Montadert et al. (1979), and Chenet et al. (1982) as being the boundary between brittle and ductile continental crust, i.e., the fault surface where listric normal faults root. This interpretation implies that the upper part of the acoustic basement consists of several tilted crustal blocks, one of which constitutes the north-trending ridge near the $12^{\circ} 30^{\prime} \mathrm{W}$ meridian (Fig. 3). According to this interpretation, the acoustic basement above the $\mathrm{S}$ reflector should be continental basement and/or pre-rift sediments.

\section{Ocean/Continent Transition}

Near the foot of the continental margin and approximately in line with magnetic anomaly M0 is a ridge of basement rocks that trends north nearly along the $13^{\circ} \mathrm{W}$ meridian (Fig. 5). This ridge is buried beneath sediments along much of its extent but crops out locally at Hill 5100 (Fig. 3). Dredging along the west side of Hill 5100 recovered a large sample of serpentinized peridotite derived from the upper mantle (Boillot et al., 1980). Perhaps because of the serpentinization of the peridotite, the ridge shows no peculiar magnetic or gravimetric signature (Guennoc et al., 1979; Lalaut et al., 1981).

The ridge of basement rocks that crops out at Hill 5100 is between the Iberian Abyssal Plain to the west, where all available geophysical data indicate a typical oceanic crust (Grau et al., 1973), and the lower part of western Galicia margin to the east, where seismic profiling shows probable tilted blocks, i.e., rift structures resulting from stretching of the continental crust. The ridge where peridotite crops out is near the boundary between oceanic and continental crust. According to Boillot et al. (1980), this ridge may be the result of serpentinite diapirism and tectonic denudation of the mantle rocks along the rift axis of the margin just before seafloor spreading started between Galicia and Newfoundland.

\section{Stratigraphy and Seismic Correlations}

One site on the northwest Iberian margin (Site 398) was drilled during DSDP Leg 47B in 1976 (Sibuet, Ryan, et al., 1979, 1980). At this site, nearly the whole post-rift section (uppermost Aptian-Holocene) and a part of the syn-rift sediments (Hauterivianupper Aptian) were recovered as cores. The drill neither reached the base of the syn-rift section nor sampled the pre-rift strata or crystalline basement rock (Fig. 7).

Basement rock and overlying pre-rift sediments have been sampled only by dredges (Black et al., 1964; Dupeuble et al., 1976; Boillot et al., 1979; Mougenot et al., 1985), which recovered (1) shallow-water platform carbonates of Late Jurassic to earliest Cretaceous age, locally interbedded or capped by micrite with calpionellids (Dupeuble et al., this volume), (2) unfossiliferous red sandstone, lithologically similar to Triassic continental sediments in the Portugal Basin, and (3) metamorphic or granitic rocks, similar to the crystalline basement rocks cropping out onshore on Galicia or Portugal.

Drilling results at Site 398 indicate that the syn-rift sediments of the Lower Cretaceous are detrital and were derived in part 

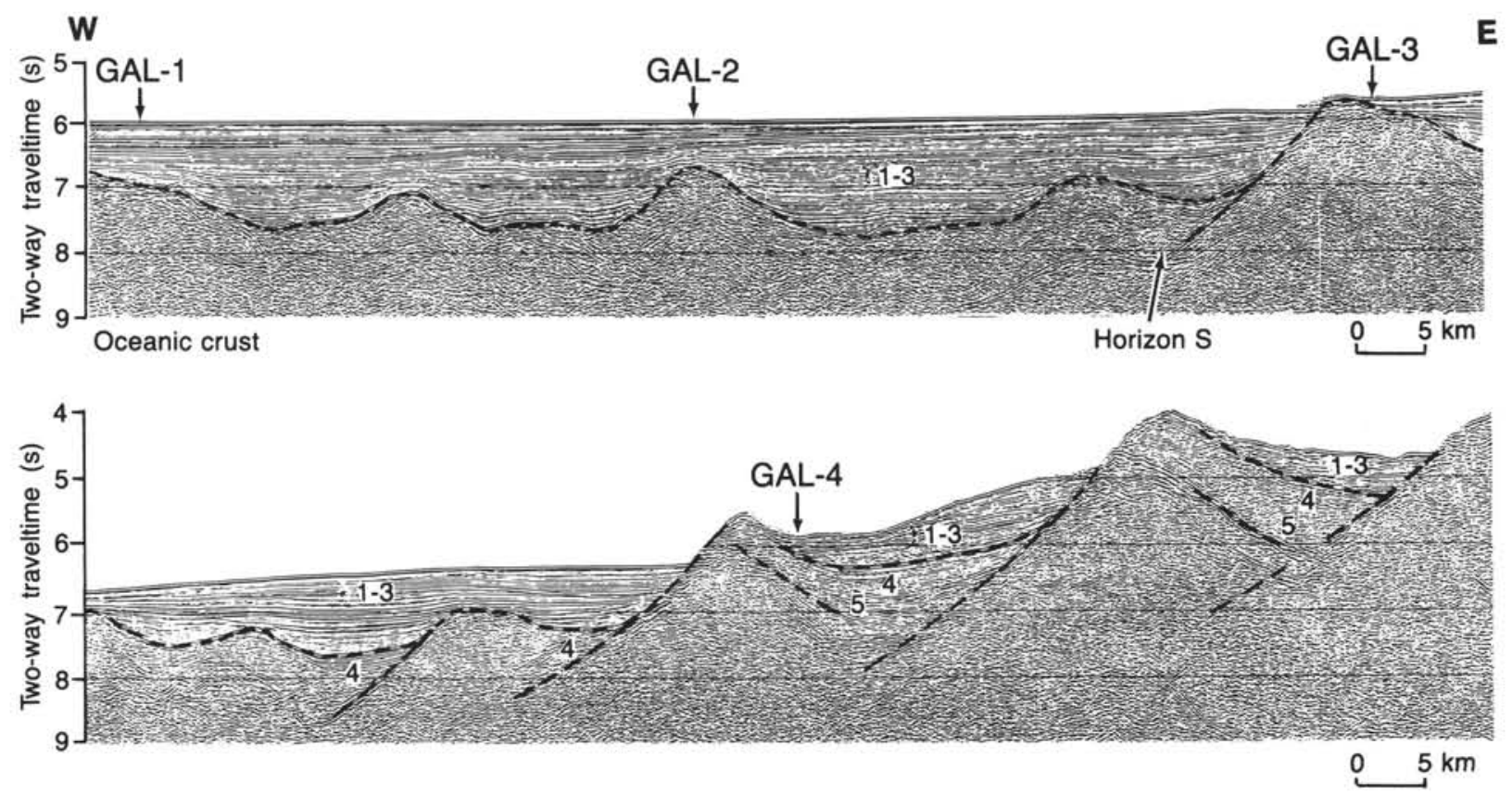

Figure 6. Line GP-11 seismic profile, 24-fold, migrated, showing cross section from the oceanic crust to the Galicia margin across the oceanic/continental-crustal boundary and tilted fault blocks. Seismic units $1-5$ are discussed in text. Vertical exaggeration, 3.3. Locations of target drill sites GAL-1 through GAL-4 are projected along this seismic line. Courtesy of L. Montadert.
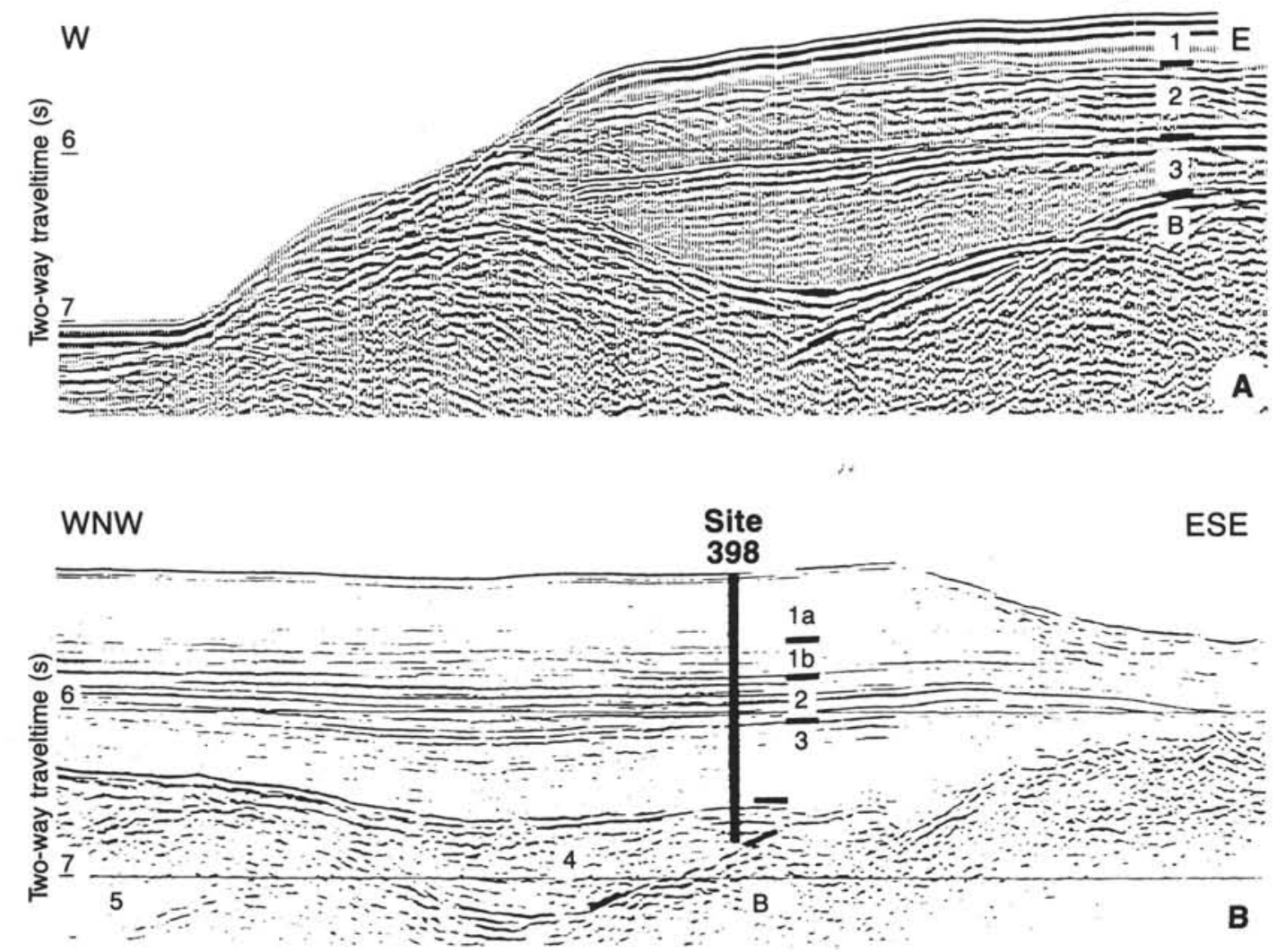

Figure 7. (A) Acoustic stratigraphy on abyssal plateau west of Galicia margin (profile OC-106). (B) Acoustic stratigraphy near DSDP Site 398 (profile GP-19). Units 1, 2, 3, and 4 are seismic units described in the text. Unit 5 was interpreted before Leg 103 as being pre-rift deposits; Unit B was interpreted as being crystalline basement. From Groupe Galice (1979). 
from erosion of an Upper Jurassic carbonate platform. On seismic-reflection records, these sediments appear to fill in the elongate half grabens of tilted fault blocks (acoustic unit 4; Fig. 7). Reflectors are moderately to strongly layered but are locally discontinuous or confused. In some basins, the reflectors diverge downdip, probably mainly in response to rotation of the basement blocks along listric faults during sedimentation (Groupe Galice, 1979).

On the basis of foraminiferal data, the oldest dateable strata directly overlying the post-rift unconformity are early Albian, whereas the youngest dateable strata immediately below are late Aptian (Sigal, 1979). This indicates a small hiatus of little more than a substage or perhaps only a somewhat condensed section. At the level of this hiatus, the lithology changes from dark marly mudstone with abundant debris flows and turbidites below to mainly laminated black shale above. The late Aptian age for this change and probable unconformity corresponds fairly well to the age of anomaly M0, which is identifiable near the foot of the margin west of Site 398, and indicates that rifting ceased and accretion of oceanic crust began at about $110 \mathrm{Ma}$ in this region.

The post-rift sequence at Site 398 begins with acoustically transparent black mudstone and shale (acoustic unit 3; Fig. 7), representing distal turbidites rich in organic debris, deposited between early Albian and middle Cenomanian time. These strata partly fill in depressions that remained after syn-rift sedimentation. The Upper Cretaceous and lower Cenozoic (middle Cenomanian to middle Eocene) section is incomplete and condensed. These are essentially pelagic deposits and appear on the seismicreflection profiles as strong, parallel reflectors (acoustic unit 2; Fig. 7). The upper Eocene to Holocene section (acoustic unit 1; Fig. 7) is locally unconformable on older strata (Pyrenean discordance, which is most strongly developed north of the Iberian Peninsula; Grimaud et al., 1982). Acoustic unit 1 consists of pelagic sediments with interbedded turbidites.

\section{Evolution and Structure of the Margin as Visualized before Leg 103 Drilling}

From the data available before the beginning of Leg 103, the following model of evolution and structure of the Galicia margin was constructed:

1. A first(?) rifting stage during Early Triassic-Late Triassic time was postulated mainly on the basis of land (Lusitanian Basin), rather than marine, data. We tentatively assign the red sedimentary rocks dredged from the margin by Mougenot et al. (1985) to this epoch.

2. During Late Jurassic to earliest Cretaceous time, a shallowwater carbonate-platform environment prevailed over nearly the whole margin. Variations in thickness of the carbonates, inferred from seismic profiles, may be due to tilting of the basement rock produced during an early stage (Late Jurassic) of rifting.

3. The carbonate platform broke up mainly during Early Cretaceous time, at least as early as the Hauterivian, and produced the basin-and-range (fault-block) topography, of which remnants are evident today (Fig. 3). Rapid subsidence in the basin caused rapid increases in water depth, and some basinal sediments at Site 398 were being deposited below the calcite compensation depth (CCD) as early as Barremian time (Sibuet, Ryan, et al., 1979).

4. The post-rift evolution, from late Aptian to Holocene time, began with continued but gradual subsidence of the whole margin. At Site 398, distal turbidites (now black shales) accumulated below the CCD until middle Cenomanian time; then pelagic-clay accumulation prevailed during the Late Cretaceous.

5. The normal evolution of the margin was interrupted by tectonic activity during the Late Cretaceous and early Cenozoic. At Site 398, the occurrence of calcareous sediments in the Maes- trichtian suggests uplift of that area to a height above the CCD during the latest Cretaceous. Tectonism along the Pyrenean margin of Iberia during Paleocene and Eocene times produced the numerous plateaus and seamounts on Galicia margin (Boillot et al., 1979; Mougenot et al., 1984). A less important tectonic event (reactivation of former faults) also occurred during the Miocene. One of the main results of all this tectonism in the region was the increase in the supply rate of detrital sediments to the margin (Rehault and Mauffret, 1979).

\section{LEG 103 DRILLING OBJECTIVES AND TARGET SITES}

The coring and logging program during Leg 103 was designed to elucidate the history of rifting, subsidence, and sedimentation on Galicia margin and the relationship of these processes to the beginning of seafloor spreading and progressive opening of the adjacent North Atlantic. The results of this study should also greatly aid in understanding the evolution of the conjugate margin of North America. Beyond addressing regional problems, the cruise attempted to gain new data on the more general problems of the oceanic/continental-crustal transition, the possible tectonic denudation of mantle rocks during rifting, and the geologic and geophysical evolution of passive continental margins.

The initial drilling proposal submitted to the JOIDES office by Mauffret et al. (1984) consisted of drilling four sites along a transect from the oceanic Iberian Abyssal Plain to the deep Galicia margin (Fig. 8). These four sites are as follows:

1. Target site GAL-1 was on the Iberian Abyssal Plain, on top of a buried basement high assumed to be oceanic crust. The objective of drilling this site was to date the beginning of seafloor spreading by recovering the oldest sediments and the oceanic basement rock near the oceanic/continental-crustal boundary. Site GAL-1 was classified as a secondary priority and was not drilled during Leg 103.

2. Target site GAL-2, on the ridge from which peridotite had been dredged, was expected to provide data on the petrologic nature of the basement and on its possible heterogeneity. Sampling unaltered peridotite was to permit petrographic and chemical studies to constrain the origin of the ultrabasic rocks. Structural fabric studies were planned to obtain clues to the original deformation history of the rocks in the mantle and their later deformation as they were emplaced, possibly as diapirs, into the crust. Target site GAL-2 became Site 637, drilled during Leg 103 (see Site 637 chapter, this volume).

3. Target site GAL-3 was proposed as a single-bit hole at the summit of the tilted block of the margin closest to the ocean, i.e., where the $\mathrm{S}$ reflector occurs within the upper part of the acoustic basement. The objective of drilling this site was to obtain an understanding of the nature of the tilted block. Target site GAL-3 became Site 640, drilled during Leg 103 (see Site 640 chapter, this volume).

4. Target site GAL-4 was proposed to sample the whole sequence of syn- and pre-rift strata and the underlying continental basement rock near the top of a typical tilted block of the deep margin. The cores and downhole logs from this site should give us nearly the entire history of the margin, from the succession of rifting phases during the Mesozoic through the drowning of the carbonate platform and the progressive or sudden changes in environment during the initiation of seafloor spreading. Cores from the crystalline basement will permit comparisons with the exposed basement rock of Galicia and Newfoundland. Site GAL-4 was planned as a deep, multiple reentry hole. Difficulties with drilling operations during Leg 103 forced us to change this proposed drilling strategy and, instead, to piece together the synand pre-rift section by drilling several complementary single-bit holes (Sites 638, 639, and 641; see site chapters, this volume). 


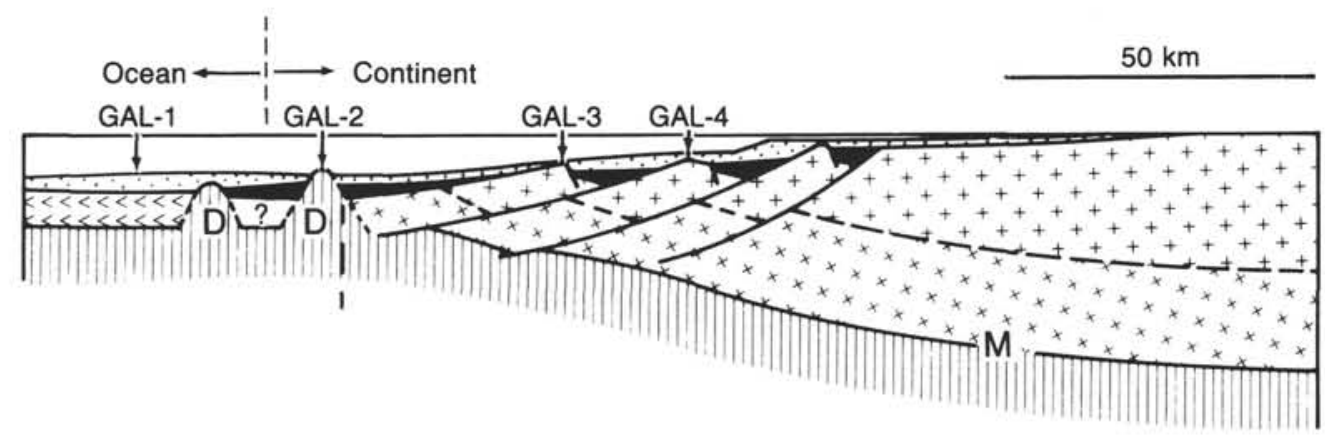

Figure 8. Model of the Galicia margin proposed by Boillot et al. (1980). Crustal thinning results from tectonic extension that produces listric faulting extending to the middle or to the base of the crust. Near the oceanic/ continental-crust boundary, the highly thinned crust may consist of granulite-facies rocks. The possibility of serpentinite diapirism is enhanced by the proximity of the mantle to the earth's surfaces. $\mathrm{D}=$ serpentinite diapir; $M=$ Mohorovičić discontinuity. Locations of target sites GAL-1 through GAL-4 are also shown in Figure 6.

\section{DRILLING RESULTS}

\section{Site 637: Exposure of the Upper Mantle During Rifting}

The Galicia continental margin is bounded to the west by a north-trending basement ridge, $10 \mathrm{~km}$ wide and more than $60 \mathrm{~km}$ long, near the boundary between oceanic and continental crusts. This ridge is buried beneath sediments along much of its extent but crops out locally at Hill 5100 (Figs. 9 and 10). Seismic data suggest that Lower Cretaceous syn-rift sediments, deposited just before seafloor spreading began in this part of the North Atlantic Ocean, occur in the basin immediately to the east of this basement ridge. Dredging along the west side of Hill 5100 recovered a large sample of serpentinized peridotite derived from the upper mantle (Boillot et al., 1980).

Anticipating the recovery of peridotite by drilling the ridge, we concentrated upon the nature and emplacement of these upper mantle rocks. Structural, textural, mineralogical, and geochemical studies of the core were to focus on the emplacement process and history of the peridotite, on its nature (i.e., suboceanic or subcontinental), and on its alteration (serpentinization) and brecciation.

Drilling results on the east side of the ridge at Site 637 show that the ridge consists, at least in part, of serpentinized peridotite, confirming the previous dredging results (see Site 637 chapter, this volume). Overlain by a 212 -m-thick cover of Neogene clay and turbidite sand, $74 \mathrm{~m}$ of peridotite was penetrated from 212 to $285.6 \mathrm{~m}$ below seafloor (mbsf) at Site 637. The peridotite is clinopyroxene-bearing spinel harzburgite, which is more than $90 \%$ serpentinized and is cut by veins of calcite and serpentine (Fig. 11). Locally, the peridotite contains rare plagioclase rimming the spinel crystals.

Thin sections of the peridotite show both porphyroclastic and mylonitic textures, the latter being restricted to thin shear zones. The pervasive foliation dips about $30^{\circ}-45^{\circ}$ in the upper $50 \mathrm{~m}$ of the section, increasing to about $65^{\circ}$ in the lower $20 \mathrm{~m}$. Lineation formed by elongate pyroxene and spinel crystals is downdip. Shipboard magnetic data show that the foliation and shear planes dip to the east. Analysis of the mylonitic texture in the shear zones consistently shows a top-to-the-east sense of shear on surfaces that dip east. After shearing, the peridotite was intensively serpentinized then fractured. During the late stages of deformation, calcite and serpentine replaced and infilled fractures.

Although the peridotite at Site 637 conceivably is part of a slice of Hercynian peridotite, we deem this unlikely. The hightemperature, low-pressure environment indicated by the mineralogy (plagioclase-spinel assemblage) of the core samples contrasts with the higher pressure and lower temperature conditions (spinel-garnet assemblage) inferred for Hercynian peridotite on the Galicia mainland. The rocks at Site 637 represent suboceanic mantle, less depleted than most oceanic peridotite, or subcontinental mantle. In any case, the rocks were probably emplaced during late rifting of the margin as a result of the stretching of the lithosphere.

The Neogene sediments overlying the peridotite comprise three lithologic units. From oldest to youngest, these include (1) upper Miocene (and possibly older) pelagic and hemipelagic brown and reddish clay (180-212 mbsf), (2) upper Miocene to middle Pliocene interbedded marl and calcareous turbidites and lesser amounts of brown clay (135-180 mbsf), and (3) middle Pliocene to upper Pleistocene turbidites probably derived from the Iberian mainland (0-135 mbsf).

Standard Schlumberger logs were obtained from an interval that includes about $35 \mathrm{~m}$ of basement and $110 \mathrm{~m}$ of overlying sediments. In the sediments, the sonic log measured a nearly constant sound velocity of $1.6 \mathrm{~km} / \mathrm{s}$. In the basement, velocities increase downward from 1.6 to $3.5 \mathrm{~km} / \mathrm{s}$. Laboratory measurements of sound velocity in the peridotite yielded values ranging from 2.9 to $4.7 \mathrm{~km} / \mathrm{s}$, clustering around $3.7 \mathrm{~km} / \mathrm{s}$. The differences in measured peridotite velocities appear to result from differences in the extent of serpentinization and calcite replacement; the most altered peridotite has the lowest velocity. Generally, velocities measured parallel to the foliation are higher than those measured normal to it.

\section{Sites 638, 639, and 641: Timing and Processes of Rifting}

The fundamental processes associated with the evolution of a passive continental margin, such as crustal thinning, faulting, and subsidence, cannot be clearly understood without a knowledge of the timing of events. This was the broad objective of drilling at Sites 638, 639, and 641 (Figs. 9, 12, and 13), originally planned as a single deep hole. A summary compilation of the stratigraphic results of drilling at these three sites is shown in Figure 14; Figure 15 shows the probable geometrical/geological relationships among the six holes drilled at Site 639 , which were used to construct the stratigraphic column shown in Figure 14.

Cores from Sites 638 and 639 were collected to yield reliable data on the early history of the margin, on the timing of rifting, and on the timing of paleoenvironmental changes in this region of the North Atlantic. The purpose of drilling Site 641 was to complete the coring of the upper part of the syn-rift sediments and to core the lower part of the post-rift sequence, to date the break-up unconformity and document the timing of the cessation of rifting, and to recover the Upper Cretaceous-Albian in- 
A

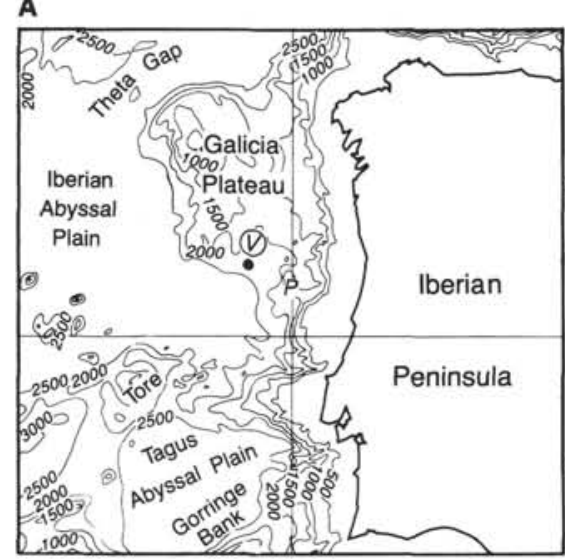

B

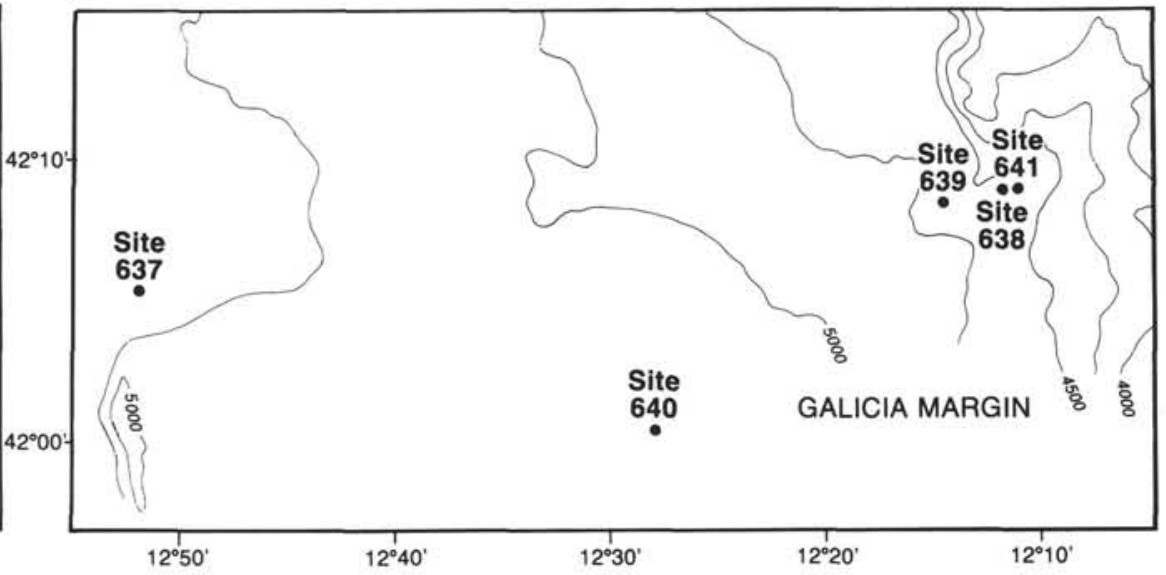

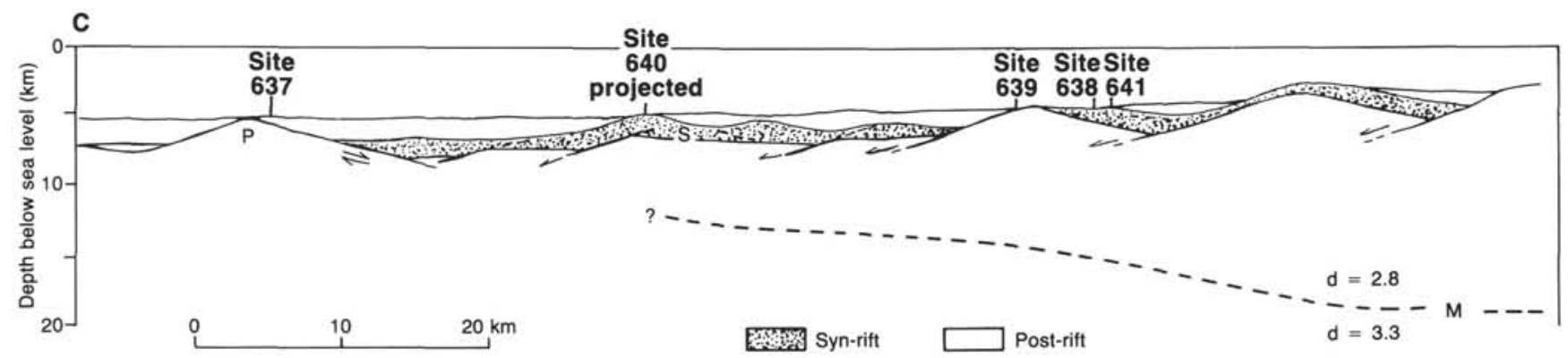

Figure 9. (A) Location map of Galicia margin northwest of the Iberian Peninsula. V = Vigo Seamount. P = Porto Seamount. (B) Bathymetric map showing location of sites drilled during ODP Leg 103. Modified from Sea Beam map; contour interval, $250 \mathrm{~m}$. (C) Schematic cross section across Galicia margin drawn from seismic data and drilling results. $\mathrm{S}$ reflector is discussed in text. $\mathrm{P}=$ peridotite ridge. Low-angle listric faults beneath half grabens are hypothetical.

terval, especially Albian-Cenomanian black shales and strata at the Cenomanian/Turonian boundary.

The sedimentary sequence, constructed from the results of drilling at these sites and summarized in stratigraphic order, includes the following units:

1. A layer of conglomerate or breccia that may lie between the Tithonian beds (see following text) and basement rock. The layer contains a great variety of low-grade metamorphic rocks of sedimentary origin, probably Paleozoic in age, and silicic volcanic or hypabyssal rocks of rhyolitic or rhyodacitic composition, which may be a part of the basement rock.

2. About $400 \mathrm{~m}$ of Upper Jurassic (Tithonian) and possibly lowest Cretaceous limestone with lesser amounts of sandstone and claystone, deposited in relatively shallow water before or during the earliest stages of rifting. The uppermost $250 \mathrm{~m}(?)$ of the limestone section were thoroughly dolomitized and cut by several generations of veins and fractures. Neither the causes nor the timing of the dolomitization are yet known. Many of the limestone samples from this interval resemble dredge samples previously recovered from a steep escarpment $6 \mathrm{~km}$ northwest of Site 638 (Fig. 12B; Mougenot et al., 1985).

3. About $40 \mathrm{~m}$ of lower Valanginian calpionellid-bearing marlstone, probably deposited at moderate depth not long after the onset of rifting and rapid subsidence.

4. Four hundred meters of upper Valanginian and Hauterivian interbedded turbidite sandstone and claystone rich in terrestrial plant debris, and Barremian and Aptian alternating clay, calcareous clay, marl/marlstone, and clayey limestone, including thin turbidites and debris flows, deposited in deep water during rifting.

5. As much as $1500 \mathrm{~m}$ of sediments deposited after rifting ceased and oceanic spreading commenced between Iberia and Newfoundland. Because the post-rift section had been cored continuously during DSDP Leg 47B, only some of the Cenozoic clay and calcareous ooze and the Albian-Maestrichtian black shale, clay, and marl parts of this section were cored during Leg 103.

The main findings of drilling at Sites 638, 639, and 641 are as follows:

1. Lower Cretaceous turbidite beds occur beneath the reflector previously identified on seismic records as the top of the prerift carbonate platform, necessitating a reassessment of the regional seismic stratigraphy beneath the break-up unconformity and revealing new information on the history of the Galicia margin by extending the syn-rift period back to at least the Valanginian.

2. Tithonian limestone rests either directly on basement rock or on a thin basal conglomerate that in turn rests on basement rock, suggesting that this region remained a structural high, possibly even a source of sediments, until late into the Jurassic. This implies that the Leg 103 area, which was a locus of maximum thinning and rifting of the crust, near the origin of the laterformed first oceanic crust, was in a region that had been a structural high until the latest part of the Jurassic and was not in a region with a preceding history of rifting, subsidence, and sedimentation. 
A

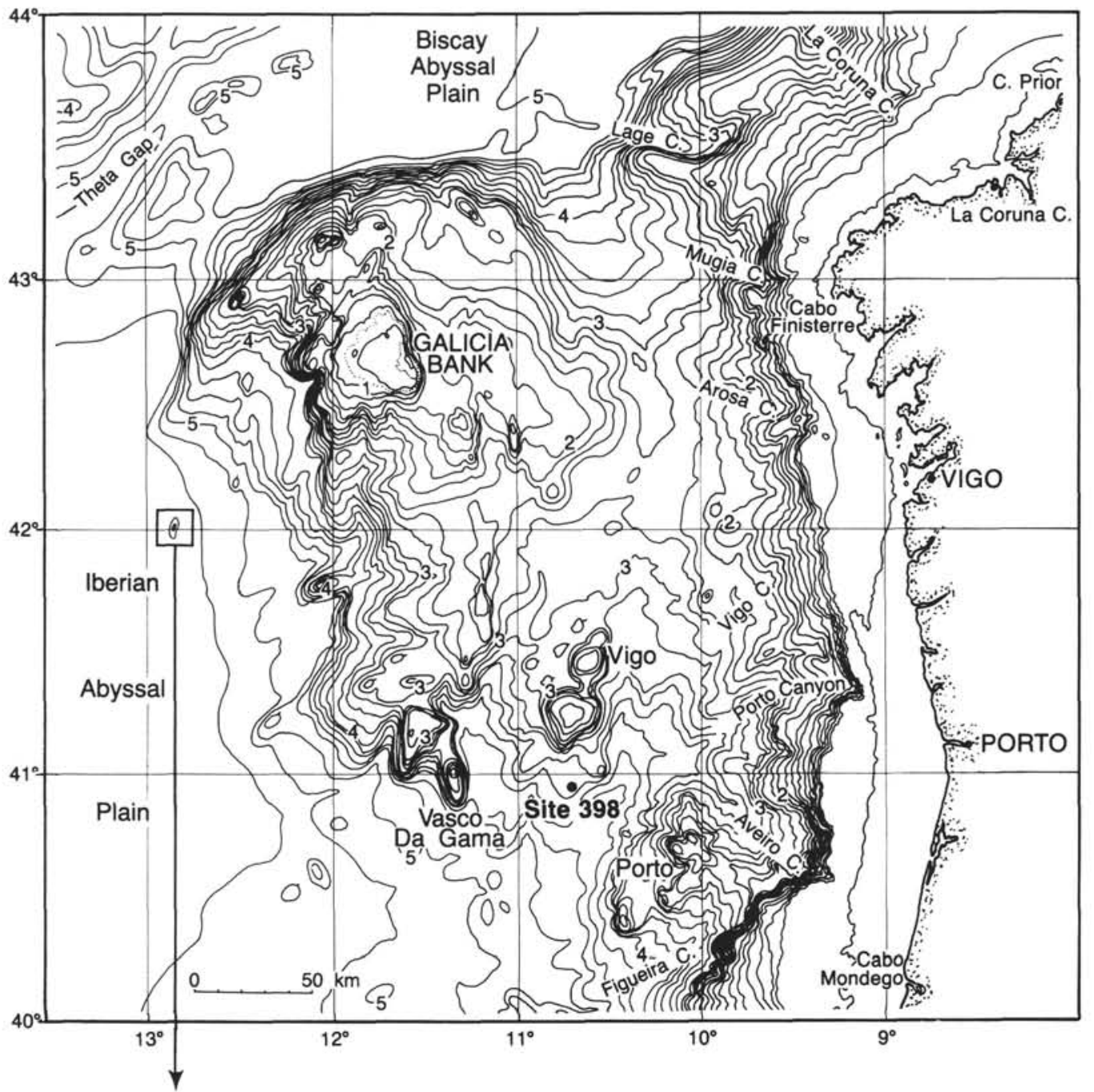

B

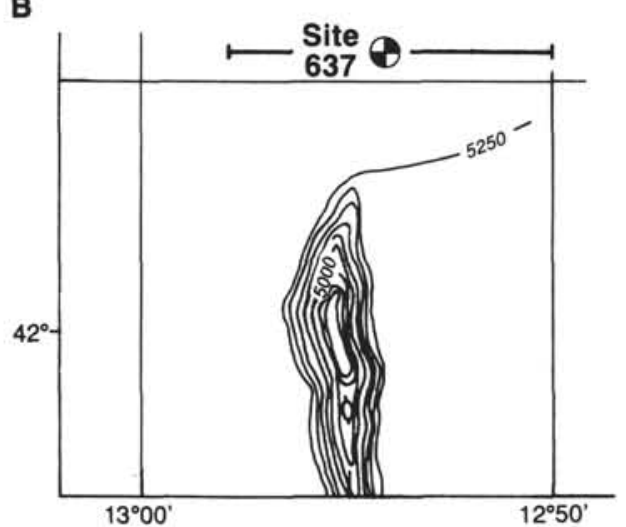

C

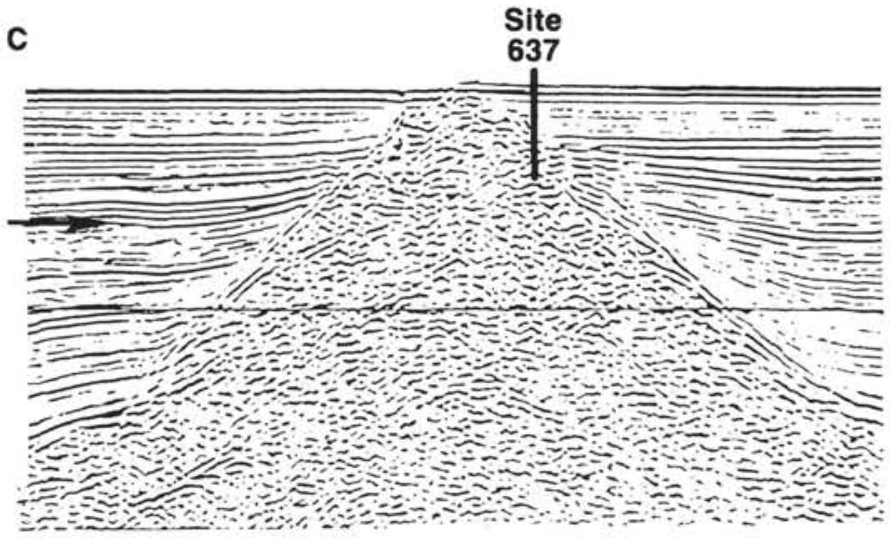

Figure 10. Location of Site 637 on (A) regional bathymetric map, (B) Sea Beam map, and (C) seismic line GP-12. Courtesy of J. R. Vanney, J. C. Sibuet, and L. Montadert.

3. Tectonic distension and deepening of the margin occurred in several stages. Several hundred meters of subsidence occurred during the Tithonian to accommodate the shallow-water carbonate beds. Whether this was the beginning of rifting or a renewal or continuation of older subsidence is not known. The carbonate platform was faulted and drowned sometime during the latest Tithonian to earliest Valanginian interval. Subsequently, the platform was partly buried by syn-rift sediments, which progressively filled individual basins formed by tilting of fault blocks along listric(?) normal faults. Seismic stratigraphy and coring clearly reveal that faulting and associated subsidence began at least as early as the very Early Cretaceous and continued episodically for about $25 \mathrm{~m}$.y. from early Valanginian through late Aptian times. Magnetic reversal M0 occurs in lower Aptian stra- 


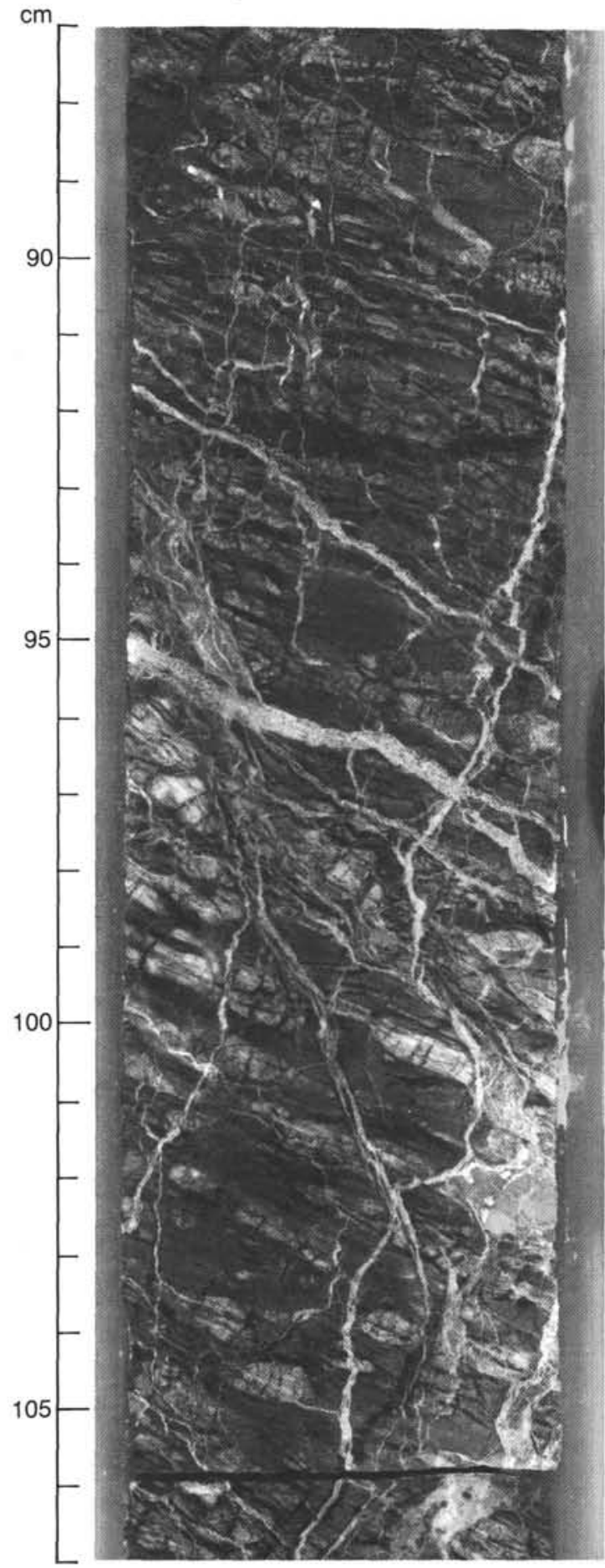

Figure 11. Sample 103-637A-26R-2, 87-107 cm. Altered and foliated peridotite typical of basement rocks recovered at Hole 637A. Foliation is defined by elongation of pyroxene crystals and bands of serpentine. Veins are calcite and serpentine and are generally subperpendicular or subparallel to the main foliation.

ta at Site 641 , about $30 \mathrm{~m}$ below the base of the overlying postrift sedimentary sequence. This helps explain why the M0 (J) magnetic anomaly cannot be recognized west of Galicia margin; there seafloor spreading began later.

4. The early post-rift sequence includes at least $50 \mathrm{~m}$ of $\mathrm{Al}$ bian black and gray claystone ("black shales") conformably overly- ing Aptian turbidites and debris flows of the syn-rift sequence. Although sedimentation changes abruptly, the "break-up unconformity" is not recognizable in the cores as an angular unconformity or as a hiatus in the biostratigraphy.

Downhole logs of natural gamma-ray spectrometry, resistivity, sonic velocity, bulk density, and neutron porosity were taken over the interval from about 105 to 270 mbsf at Site 638 , from about 168 to $260 \mathrm{mbsf}$ at Site 639 , and from 130 to $196 \mathrm{mbsf}$ at Site 641 . The log results from Site 638 , in combination with laboratory measurements of velocity and density, provide an estimate of an undrilled thickness of about $40-75 \mathrm{~m}$ between the bottom of Hole $638 \mathrm{C}$ and the top of the carbonate platform drilled at Site 639.

\section{Site 640: Structure of the Deep Margin}

Between the tilted block drilled at Sites 638 and 639 and the peridotite ridge drilled at Site 637, the deep margin of Galicia is about $50 \mathrm{~km}$ wide. The seafloor, which slopes gently to the west, is broken by only one small seamount at $42^{\circ} 09^{\prime} \mathrm{N}, 12^{\circ} 32^{\prime} \mathrm{W}$, which marks the outcrop of a buried north-trending ridge that brings "acoustic basement" (actually a zone of incoherent reflections) close to the seafloor (Fig. 16). The two north-trending sedimentary basins that flank the ridge contain thick (2-3 km) syn- and post-rift sedimentary sequences. Clearly, the buried basin-andrange topography of the "acoustic basement" is pre-Albian because it lies beneath the break-up unconformity.

In this region, the S reflector (see "Regional Background" section, this paper) is between 1.5 and $3 \mathrm{~s}$ (two-way traveltime) below the seafloor (Fig. 16) and is thus too deep for ODP drilling. However, drilling into the upper part of the "acoustic basement" above the S reflector should acquire new data crucial for the interpretation of that reflector and of the margin and the adjacent oceanic basin.

The stratigraphic section recovered by drilling at Site 640 includes, in order from oldest to youngest (1) Hauterivian gray nannofossil chalk and calcareous clay, grading downward to interbedded marlstone, turbidite sandstone, siltstone, and claystone, slumped in some intervals (184-232 mbsf); (2) Barremian gray clayey ooze and calcareous clay (160-184 mbsf); (3) upper Aptian-Albian gray nannofossil ooze (157-160 mbsf); and (4) brown clay, barren of fossils (145-157 mbsf). We washed through the interval from 0 to 145 mbsf without taking any cores (see Site 640 chapter, this volume).

Finding Lower Cretaceous syn-rift turbidite sediments, similar to those at Site 638 , in the acoustically incoherent unit may force reassessment of the ductile/brittle-transition interpretation of the $\mathrm{S}$ reflector because the rocks above the $\mathrm{S}$ reflector consist of Early Cretaceous sediments, more or less tilted and slumped during rifting. Thus, the $S$ reflector, lying 2 to $4 \mathrm{~km}$ below the seafloor, could be the substratum of the syn-rift Cretaceous sedimentary rocks, produced either by the top of pre-rift platform carbonates or by crystalline basement rock. The structural complexity of the Lower Cretaceous rocks and the smoothness of the $\mathrm{S}$ reflector also suggest that the reflector may mark a structural contact, e.g., a low-angle detachment fault.

\section{SUMMARY}

ODP Leg 103, which began on 25 April 1985 in Ponta Delgada, Azores, and ended in Bremerhaven, Federal Republic of Germany, on 19 June 1985, extended the results of DSDP Leg 47B through the syn- and pre-rift strata by drilling and coring through the break-up unconformity and then through $1200 \mathrm{~m}$ of Lower Cretaceous (Albian-Valanginian) to Upper Jurassic (Tithonian) rocks to the top of basement rock on the deep western edge of the margin (Sites 638, 639, and 641). The occurrence of Lower Cretaceous turbidites, beneath the seismic reflector previously interpreted as being the top of the possible pre-rift carbonate 


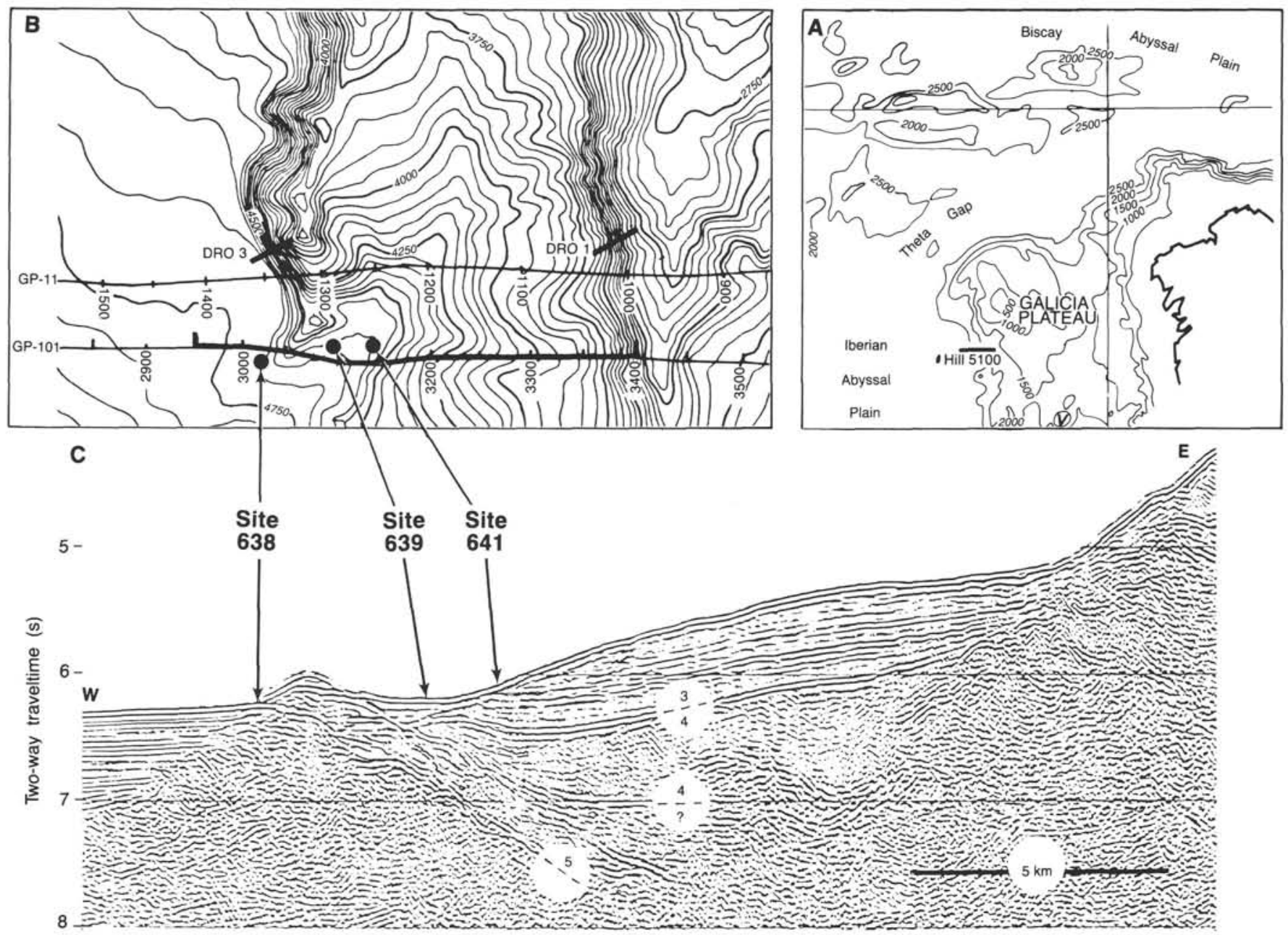

Figure 12. (A) Galicia margin. (B) Sea Beam map of the area near Sites 638,639, and 641, showing location of dredge localities DRO3 and DRO1 (Mougenot et al., 1985). After Sibuet et al. (this volume). (C) Multichannel seismic profile GP-101, showing the location of Sites 638, 639, and 641; 3, post-rift strata; 4 and 5, syn-rift strata. Courtesy of L. Montadert.

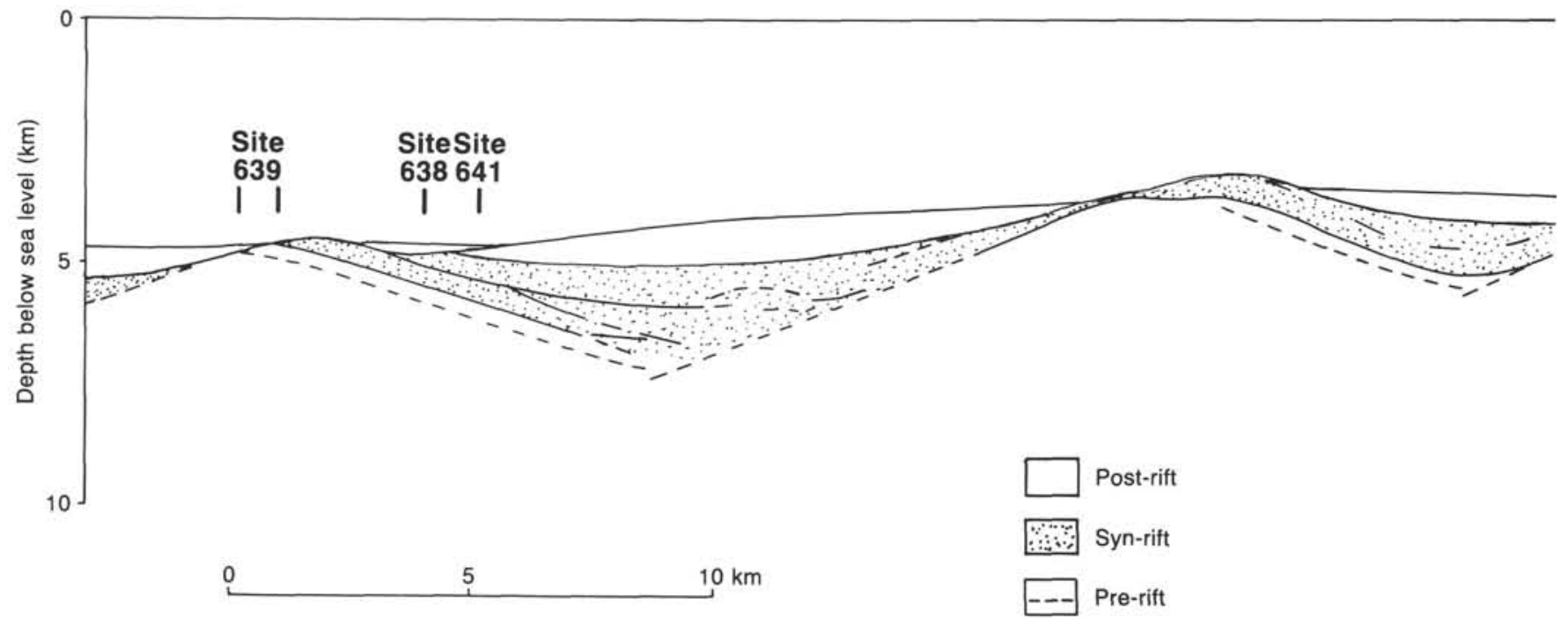

Figure 13. Schematic cross section across Galicia margin near Sites 638,639, and 641, drawn from seismic data and drilling results. The east slopes of the half grabens are faulted, but the dip of the faults is uncertain. 


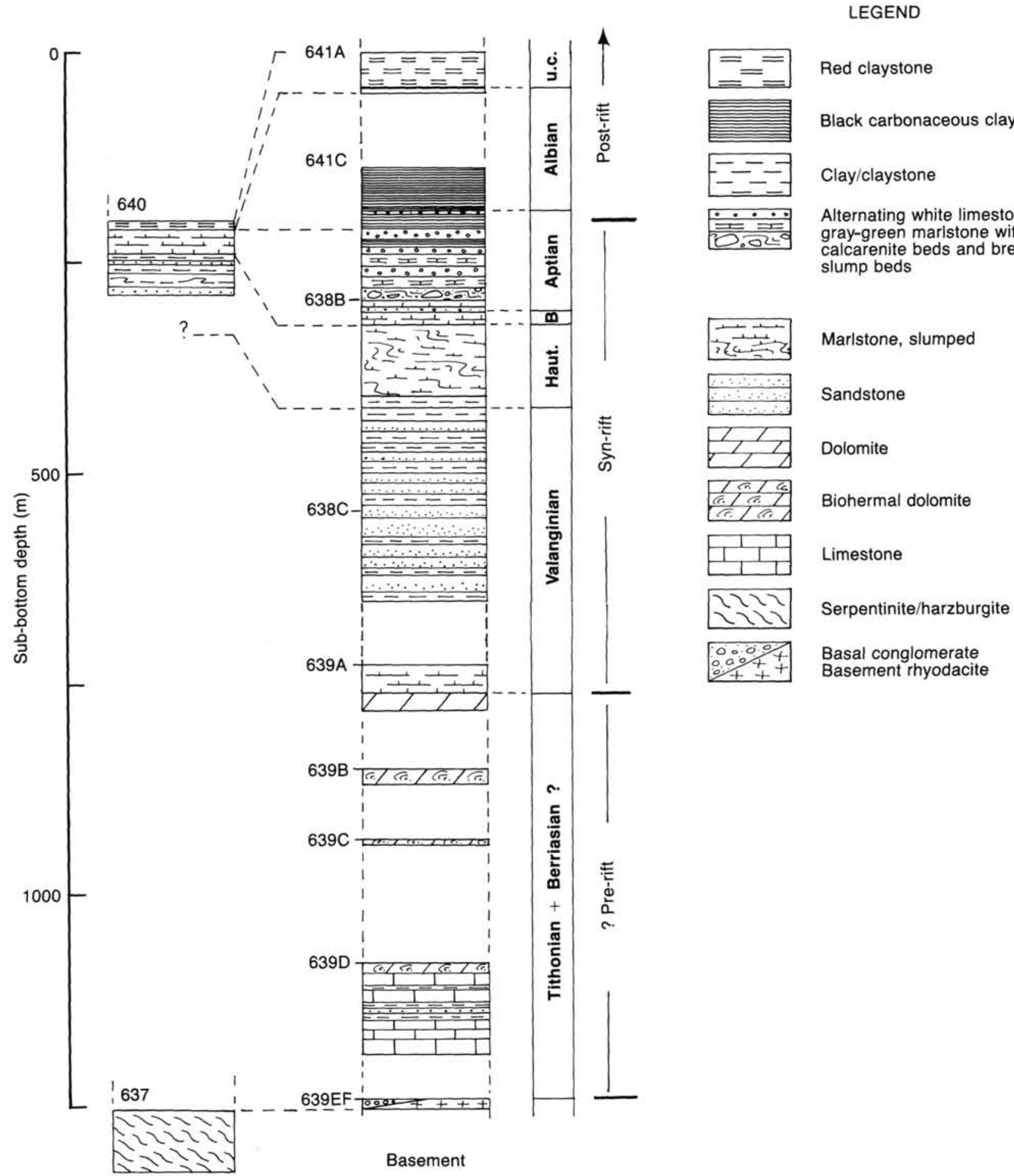

Figure 14. Leg 103 schematic stratigraphic columns. U.C. = Upper Cretaceous; B = Barremian.

platform, necessitates a reassessment of the regional seismic stratigraphy, extending the syn-rift period on Galicia margin back to at least the Valanginian. Tithonian limestone, resting either directly on basement rock or on a thin basal conglomerate overlying basement rock, implies that this region remained a structural high until late in the Jurassic.

Site 637 drilling, near the boundary between oceanic and continental crust, recovered peridotite of the upper mantle. Although this peridotite could be part of a Hercynian ophiolitic slab in- cluded in a tilted block of the continental crust, more likely it was emplaced during late rifting of the margin as a result of the stretching of the lithosphere.

Site 640 was drilled on the summit of the ridge nearest the oceanic/continental-crust transition, over the deep S reflector, previously widely thought to represent the ductile/brittle boundary in continental crust. Finding Lower Cretaceous, syn-rift turbidites in the acoustically incoherent unit above the $\mathrm{S}$ reflector indicates that the reflector marks a level near the original deposi- 


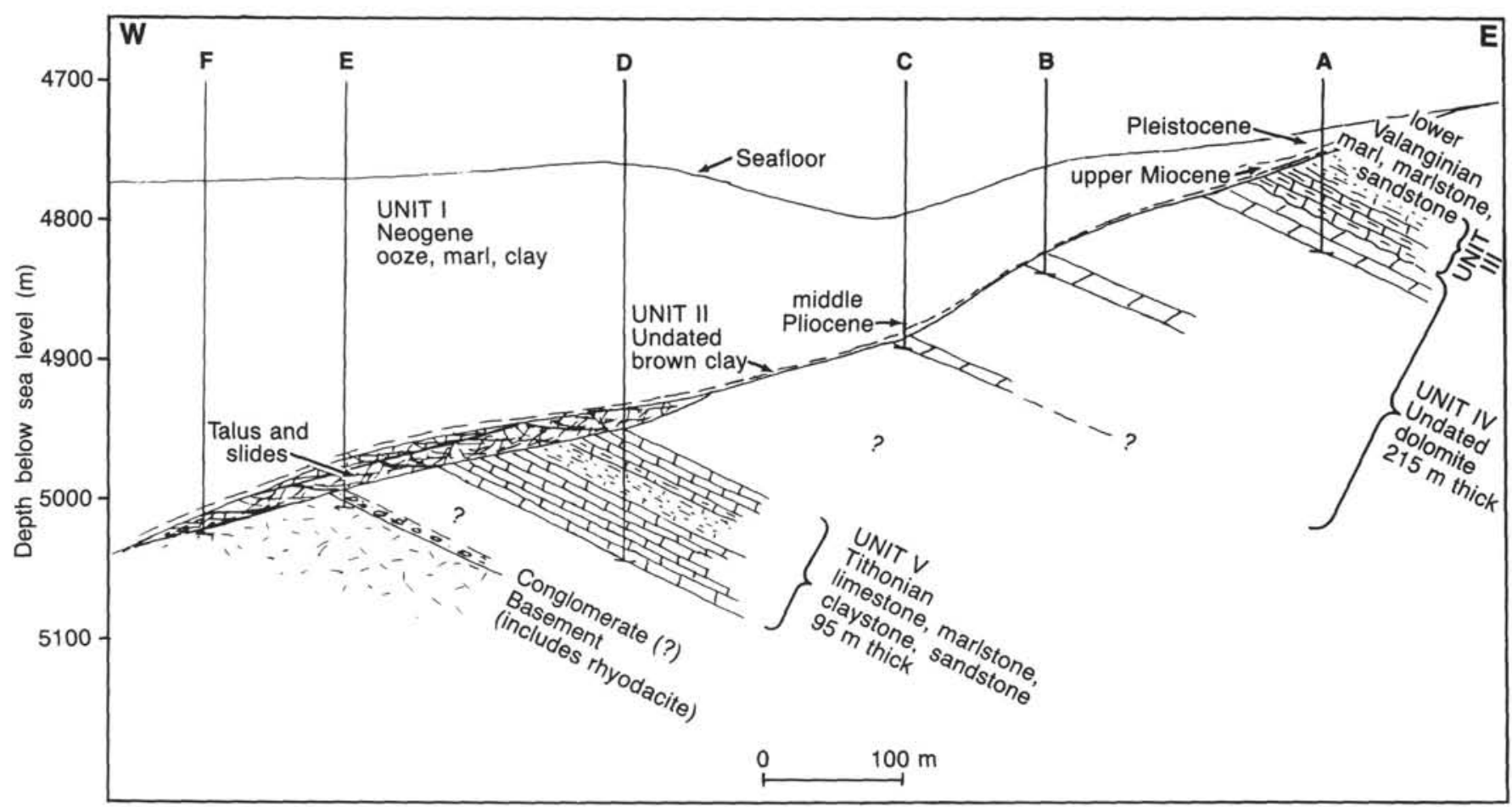

Figure 15. Geologic cross section through holes drilled at Site 639. A uniform dip of $30^{\circ}$ is assumed, based on the average of measurements on cores. Regional dip, as estimated from seismic data, is about $10^{\circ}$. No faults are shown, although some could exist. Blank spaces in the cross section indicate parts of the section unsampled during coring for which stratigraphic assignment cannot be made confidently. The brown clay, Unit II, is shown extending across the entire erosion surface that truncates the Mesozoic. The talus and rock-slide unit is drawn so that the displaced limestone at the top of the unit has a possible source farther up the slope, on limestone not covered by dolomitic talus. Rhyodacite drawn here as basement rock may be part of the basal conglomerate, and the basement may include many rocks other than rhyodacite.

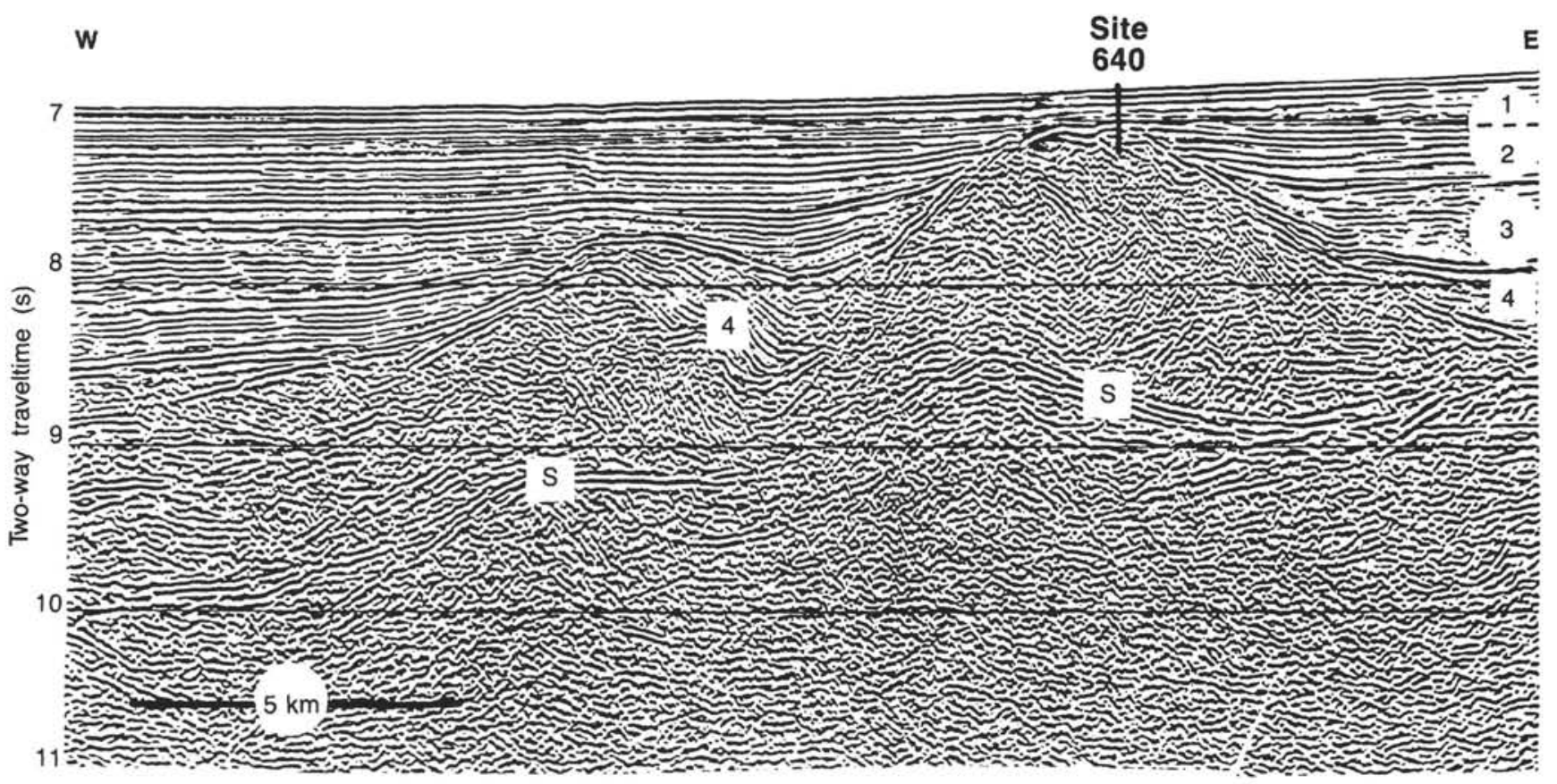

Figure 16. Multichannel seismic line GP-102B, showing location of Site 640. 1-3 = Albian-Recent post-rift sediments; $4=$ syn-rift sediments. S $=$ deep reflector in "acoustic basement." Courtesy of L. Montadert. 
tional contact between the syn-rift sediments and the underlying carbonate platform and/or the crystalline basement rock, now transformed into a detachment-fault surface.

\section{REFERENCES}

Berthois, L., Brenot, R., and Ailloud, P., 1965. Essai d'interprétation géomorphologique et géologique de la pente continentale a l'Ouest de la Péninsule Ibérique. Rev. Trav. Inst. Pêches Marit., 29: 343-350.

Black, M., Hill, M., Laughton, A. S., 1964. Three non-magnetic seamounts off the Iberian Coast. J. Geol. Soc. London, 120:477-517.

Boillot, G., 1986. Comparison between the Galicia and Aquitaine margins. Tectonophysics, 129:243-255.

Boillot, G., Auxietre, J. L., Dunand, J. P., Dupeuble, P. A., and Mauffret, A., 1979. The northwestern Iberian margin: a Cretaceous passive margin deformed during Eocene. In Talwani, M., Hay, W., and Ryan, W. B. F. (Eds.), Deep Drilling Results in the Atlantic Ocean: Continental Margins and Paleoenvironment Maurice Ewing Series 3: Washington (Am. Geophys. Union), 138-153.

Boillot, G., Grimaud, S., Mauffret, A., Mougenot, D., Mergoil-Daniel, J., Kornprobst, J., and Torrent, G., 1980. Ocean-continent boundary off the Iberian margin: a serpentinite diapir west of the Galicia Bank. Earth and Planet. Sci. Lett., 48: 23-34.

Chenet, P., Montadert, L., Gairaud, H., and Roberts, D., 1982. Extension ratio measurements on the Galicia, Portugal, and northern Biscay continental margins: implications for evolutionary models of passive continental margins. In Watkins, J. S., Drake, C. L. (Eds.), Studies in Continental Margin Geology: AAPG Mem., 34: 703-715.

de Charpal, O., Guennoc, P., Montadert, L., and Roberts, D. G., 1978. Rifting, crustal attenuation and subsidence in the Bay of Biscay. $\mathrm{Na}$ ture, 275(5682): 706-711.

Dupeuble, P. A., Rehault, J. P., Auxietre, J. L., and Pastouret, L., 1976. Résultats de dragages et essai de stratigraphie des Bancs de Galice et des montagnes de Porto et de Vigo (marge occidentale ibérique). Mar. Geol., 22: M27-M49.

Grau, G., Montadert, L., Delteil, R., and Winnock, E., 1973. Structure of the European continental margin between Portugal and Ireland from seismic data. Tectonophysics, 20: 319-339.

Grimaud, S., Boillot, G., Collette, B., Mauffret, A., Miles, P. R., and Roberts, D. B., 1982. Western extension of the Iberian-European plate boundary during the Early Cenozoic (Pyrenean) convergence: a new model. Mar. Geol., 45: 63-77.

Groupe Galice, 1979. The continental margin off Galicia and Portugal: acoustical stratigraphy, dredge stratigraphy, and structural evolution. In Sibuet, J. C., Ryan, W. B. F., et al., Init. Repts. DSDP, 47, Pt. 2: Washington (U.S. Govt. Printing Office), 633-662.

Guennoc, P., Jonquet, H., and Sibuet, J. C., 1979. Présentation d'une carte magnétique de l'Atlantique Nord-Est. Acad. Sci. Paris, C. R., D, 288: 1011-1013.

Klitgord, K. D., and Schouten, H., in press. Plate kinematics of the central Atlantic. In Tucholke, B. D., and Vogt, P. R. (Eds.), The Geology of North America: the Western Atlantic Region, 1. Geol. Soc. $A m$. DNAG Series.

Kristoffersen, Y., 1978. Seafloor spreading and the early opening of the North Atlantic. Earth and Planet. Sci. Lett., 38: 273-290.

Lalaut, P., Sibuet, J. C., and Williams, C., 1981. Présentation d'une carte gravimétrique de l'Atlantique Nord-Est. Acad. Sci. Paris, C. R., D, 292: 597-600.

Lallemand, F., Maze, J. P., Marti, F., and Sibuet, J. C., 1985. Présentation d'une carte bathymétrique de l'Atlantique Nord-Est. Acad. Sci. Paris, C. R., 300 II: 145-149.

Laughton, A. S., Roberts, D. G., and Graves, R., 1975. Bathymetry of the northeast Atlantic. Sheet 3: Mid-Atlantic Ridge to southwest Europe. Deep-Sea Res., 22: 792-810.
Mauffret, A., Boillot, G., Auxietre, J. L., and Dunand, J. P., 1978. Évolution structurale de la marge continentale du Nord-Ouest de la Péninsule Ibérique. Bull. Soc. Geol. Fr., 20: 375-388.

Mauffret, A., Boillot, G., and Montadert, L., 1984. DSDP proposal off Galicia Bank (Spain). In Some Proposals for the Scientific Drilling Program. IPOD France Scientific Committee, December 1983, 69108.

Montadert, L., de Charpal, O., Roberts, D., Guennoc, P., and Sibuet, J. C., 1979. Northeast Atlantic passive continental margin: rifting and subsidence processes. In Talwani, M., Hay, W., and Ryan, W. B. F. (Eds.), Deep Drilling Results in the Atlantic Ocean: Continental Margins and Paleoenvironment Maurice Ewing Series 3. Washington D. C. (Am. Geophys. Union), 154-186.

Montadert, L., Winnock, E., Delteil, J. R., and Grau, G., 1974. Continental margins of Galicia-Portugal and Bay of Biscay. In Burk, C. A., and Drake, C. L. (Eds.), The Geology of Continental Margins: Berlin, Heidelberg, New York (Springer Verlag), 323-342.

Mougenot, D., Capdevila, R., Palain, C., Dupeuble, P.-A., and Mauffret, A., 1985. Nouvelles données sur les sediments ante-rift et le socle de la marge continentale de Galice. Acad. Sci. Paris, C. R., t. 301, série II, 5: 323-327.

Mougenot, D., Kidd, R. B., Mauffret, A., Regnauld, H., Rothwell, R. G., and Vanney, J. R., 1984. Geological interpretation of combined Sea Beam, GLORIA, and seismic data from Porto and Vigo Seamounts, Iberian continental margin. Mar. Geol. Res., 6: 329-353.

Mougenot, D., Vanney, J. R., Mauffret, A., and Kidd, R. B., 1986. Les montagnes sous-marines de la marge continentale nord-portugaise. Bull. Soc. Geol. Fr., 8(II): 401-412.

Olivet, J. L., 1978. Nouveau modèle d'evolution de l'Atlantique nord et central. Thèse d'Etat. Paris.

Olivet, J. L., Bonnin, J., Beuzart, P., and Auzende, J. M., 1984. Cinématique de l'Atlantique nord et central. Centre National pour l'Exploration des Océans, Rapp. Sci. Tech. 56.

Rehault, J. P. and Mauffret, A., 1979. Relationship between tectonics and sedimentation around the northwestern Iberian margin. In $\mathrm{Si}$ buet, J. C., Ryan, W. B. F., et al., Init. Repts. DSDP, 47, Pt. 2: Washington (U.S. Govt. Printing Office), 663-682.

Roberts, D. G., and Kidd, R. B., 1984. Sedimentary and structural patterns on the Iberian continental margins: an alternative view of continental margin sedimentation. Mar. Petrol. Geol., 1:37-48.

Schouten, H., Srivastava, S. P., and Klitgord, K. D., in press. Iberian plate kinematics: the African connection. Nature.

Sibuet, J. C., and Ryan, W. B. F., 1979. Site 398: evolution of the west Iberian passive continental margin in the framework of the early evolution of the north Atlantic Ocean. In Sibuet, J. C., Ryan, W. B. F., et al., Init. Repts. DSDP, 47, Pt. 2: Washington (U.S. Govt. Printing Office), 761-775.

Sibuet, J. C., Ryan, W. B. F., et al., 1979. Init. Repts. DSDP: 47, Pt. 2, Washington (U.S. Govt. Printing Office).

Sibuet, J. C., Ryan, W. B. F., Arthur, M., Barnes, R., Blechsmidt, G., de Charpal, O., de Graciansky, P. C., Habib, D., Iaccarino, S., Johnson, D., Lopatin, B. G., Maldonado, A., Montadert, L., Moore, D. G., Morgan, G. E., Mountain, G., Rehault, J. P., Sigal, J., and Williams, C. A., 1980. Deep drilling results of Leg 47B (Galicia Bank area) in the framework of the early evolution of the north Atlantic Ocean. Philos. Trans. R. Soc. London, A, 294:51-61.

Sigal, J., 1979. Chronostratigraphy and ecostratigraphy of Cretaceous formations recovered on DSDP Leg 47, Site 398. In Sibuet, J. C., Ryan, W. B. F., et al., Init. Repts. DSDP, 47, Pt. 2: Washington (U.S. Govt. Printing Office), 287-326.

Vanney, J. R., Auxietre, J. L. and Dunand, J. P., 1979. Northwestern Iberian continental margin geomorphology. Ann. Inst. Océanogr., Paris, 55:5-20. 